\title{
Track prediction of very severe cyclone 'Nargis' using high resolution weather research forecasting (WRF) model
}

\author{
D R PatTANAIK and Y V RAMA RAO
}

India Meteorological Department, Lodhi Road, Mausam Bhawan, New Delhi 110 003, India.

The recent very severe cyclonic storm (VSCS) 'Nargis' over the Bay of Bengal caused widespread destruction over Myanmar after hitting the coast on 2 May 2008. The real time forecasting of the VSCS 'Nargis' was a very difficult task as it did not follow the normal westerly/northwesterly track. In the present study, a detailed diagnostic analysis of the system 'Nargis' is carried out initially to investigate the features associated with this unusual movement and subsequently the real time forecast of VSCS 'Nargis' using high resolution advanced version weather research forecasting (WRF) model is presented. The advanced research WRF model was run for $72 \mathrm{~h}$ at $27 \mathrm{~km}$ and $20 \mathrm{~km}$ resolutions with 28,29, 30 April and 1 May as the initial conditions. The diagnostic study indicates that the recurvature of the system 'Nargis' was mainly associated with:

- upper level southerly/southwesterly steering wind at $200 \mathrm{hPa}$ level associated with anticyclonic circulation over southeastern sector of the centre of the system,

- higher SST $\left(29^{\circ} \mathrm{C}\right.$ or more) with higher positive anomalies over the region to the northeast of the cyclone centre, and

- large negative $24 \mathrm{~h}$ pressure changes and large vorticity maximum to the east of the system.

The real time track forecast using the WRF model run at $27 \mathrm{~km}$ and $20 \mathrm{~km}$ resolution based on the initial conditions of 28 April (when the system was only $550 \mathrm{~km}$ away from the Indian coast) indicated that the system had a northeasterly forecast track and was not expected to cross the Indian coast. Similarly, based on 29 April initial condition the system showed east/east-northeasterly movement towards the Myanmar coast. The east/east-northeasterly movement of the 'Nargis' was persisting in the forecast based on 30 April and 1 May initial conditions with respective landfall errors of $85 \mathrm{~km}$ and $50 \mathrm{~km}$ with $27 \mathrm{~km}$ resolution, which reduces to $30 \mathrm{~km}$ and $40 \mathrm{~km}$ respectively with $20 \mathrm{~km}$ resolution, however, with a landfall time delay of about $10 \mathrm{~h}$. Improvement of mean forecast errors at different forecast hours is noticed in WRF model run at higher resolution compared to that run at lower resolution. Thus, it is very clear that the advanced version WRF model had captured movement of the system reasonably well almost 3 days in advance. Consistence with the diagnostic analysis the WRF model forecast also indicates southerly/southwesterly strong steering wind at $200 \mathrm{hPa}$ level and maximum pressure fall to the east of the system.

\section{Introduction}

Tropical cyclones (TCs) are one of the most dangerous natural calamities throughout the globe. Every year, they cause considerable loss of life and do immense damage to property. India and Bangladesh have a coastline of more than $8000 \mathrm{~km}$, which is prone to very severe cyclone formations in the Arabian Sea and Bay of Bengal. These occur during the pre-monsoon (April-May), early monsoon (June), late and post-monsoon (SeptemberNovember) periods. Originating in both the Bay of Bengal and Arabian Sea, tropical cyclones often attain velocities of more than $160 \mathrm{~km} / \mathrm{h}$ and

Keywords. Cyclone Nargis; WRF model; track forecast; Bay of Bengal; forecast error. 
are notorious for causing intense rain and storm tides (surges) as they cross the coast of India, Bangladesh and other coasts. Strong winds, heavy and torrential rains and the cumulative effect of storm surges and astronomical tides are the three major elements of tropical cyclone disaster. This is also the basin where TCs do the most damage due to the combined effects of terrain, geography, and lack of communications. The need for sea surface temperature (SST) greater than $26.5^{\circ} \mathrm{C}$ and a deep lower level moist layer and absence of strong vertical shear for development from a tropical low to a cyclonic storm and further intensification has been referred to in many studies (Gray 1992; Frank 1977). More than 200,000 people perished in the Bhola cyclone of 1970 in Bangladesh.

The cyclonic disturbances in the north Indian Ocean move predominantly along westerly/ northwesterly direction. However, some cyclonic disturbances recurve from an initial northwesterly direction to a northerly direction (often after reaching $15-20^{\circ} \mathrm{N}$ latitude) and finally towards northeasterly direction (IMD 1996). The detailed review of the synoptic and thermodynamic characteristics to predict the movement and intensification/decay of the cyclonic storm has been discussed by Krishna Rao (1997). A review of the dynamic characteristics of the movement and intensification is given by Mohanty and Gupta (1997). The motion of TC is the result of a complex interaction between a number of internal and external influences. Environmental steering is typically the most prominent external influence on a tropical cyclone, accounting for as much as 70-90\% of the motion. Theoretical studies have shown that in the absence of environmental steering, tropical cyclones move poleward and westward due to the internal influences (Chan and Gray 1982; Elsberry et al 1987). The dominant influence on movement is the largescale environmental steering. These tracks of movement are mainly due to the normal upper airflow pattern prevailing in the cyclone period. However, many forces act on the cyclonic disturbance and consequently its motion is never along a smooth path. There is also non-linear interaction between the cyclonic disturbance and the basic current in which it is embedded. Hence, the movement of the storm depends on many factors including synoptic, thermodynamic and dynamical factors. Analysis by Srinivasan and Ramamurthy (1973) found that the position of the ridge line at $200 \mathrm{hPa}$ is seen to govern the movement to a large extent. They have seen that when the centre is north of the ridge line but within $3^{\circ}$ of it, in the majority of the cases a dominant easterly component of motion appears, whereas when the storm reaches beyond $3^{\circ}$ north of the ridge line, it gets a definite eastward motion. The recent very severe cyclonic storm (VSCS) of Bay of Bengal 'Nargis' also recurved from its north and northwesterly movement and became easterly and caused widespread destruction over Myanmar after the landfall on 2 May 2008. But it did not follow the climatological cyclone track, which leads to India or Bangladesh. Thus, it is very important to monitor the system throughout its lifespan and provide accurate track forecasts to minimize the colossal damages/losses.

Predictions of tropical cyclones have improved steadily over the last three decades, mostly due to a combination of better observations, especially the satellite and radar, improvement in dynamical models and improved understanding of physical processes and mechanisms that govern the motion of tropical cyclones. The current emphasis of international tropical cyclone research is to achieve greater accuracy of tropical cyclone track and intensity prediction, especially in the short range (48-72 $\mathrm{h}$ in advance), by maximizing the use of non-conventional data, meso-scale analysis, and the physical parameterization in nonhydrostatic environment at higher model resolution. In India, development of objective techniques for forecasting track of TCs began in 1972 (Sikka and Suryanarayana 1972) by using a computer oriented half persistence and half climatology technique. Singh and Saha (1978) used case studies for forecasting movement of TCs by adopting a primitive equation barotropic model. In recent years, Mohanty and Gupta (1997), and Gupta and Bansal (1997) have used multi-level primitive equation models with parameterization of physical processes. Quasi-Lagrangian Model (QLM) has also been implemented in IMD for operational track forecast up to $72 \mathrm{~h}$ in the year 2000. Prasad and Rama Rao (2003) have evaluated the QLM and its performance is found to be even better. In the present study, the high resolution Advanced Research WRF (ARW) meso-scale model adopted from NCAR is run at $27 \mathrm{~km}$ and $20 \mathrm{~km}$ resolution to get the real time forecast of the system 'Nargis' to investigate the capability of the model to forecast such a difficult track of the system. Initially, a detailed analysis of dynamical and thermodynamical features associated with the recurvature and eastward movement of the VSCS 'Nargis' is discussed to understand the features associated with such an unusual track of 'Nargis'. Finally, the capability of the WRF model to predict the cyclone track of 'Nargis', which was really a recurved one and thus more difficult, is discussed in the present study. Some of the diagnostic features, which are observed in association with the unusual movement of 'Nargis' is also presented in the WRF model forecasts. A brief description about the WRF model used is given in section 2. Section 3 discusses the salient features of 'Nargis'. The thermodynamical 
and dynamical features associated with the recurvature of the system 'Nargis' along with some comparisons with earlier cyclones are discussed in section 4. The results of WRF model forecasts on real time basis are discussed in section 5 and all the results are summarized in section 6 .

\section{WRF modeling system and the real time model experiments}

First the NCAR version 2.2 of Advanced Research WRF (ARW) model has been used. The model domain consists of $0^{\circ}$ to $30^{\circ} \mathrm{N}$ and $65^{\circ} \mathrm{E}$ to $105^{\circ} \mathrm{E}$ with a horizontal resolution of $27 \mathrm{~km}$ and 28 vertical sigma levels. The initial conditions for the real data cases are preprocessed through a separate package called standard initialization (SI). The output from SI is passed to preprocessor in ARW, which generates initial and lateral boundary conditions. The SI is set of programs that takes terrestrial and meteorological data and transforms them for input to ARW preprocessor program for real data cases. In the present experiments, the real time analysis field obtained from the Global Forecasting System (GFS), NCEP USA with one degree resolution is used as initial and 6-hourly forecast files as boundary conditions. For the diagnostic study the NCEP FNL analysis at $1^{\circ} \times 1^{\circ}$ grid is used during the cyclone period of 'Nargis' from 27 April to 3 May 2008.

\subsection{Overview of the WRF (ARW) model used in the present study}

Dynamics

Model domain

Horizontal grid distance

Integration time step

Map projection

Horizontal grid system

Vertical co-ordinate

Time integration scheme

Spatial differencing scheme

Radiation parameterizations

Surface layer parameterizations

Cumulus parameterization

PBL parameterization Microphysics
The cumulus convection used in this case is modified Grell scheme (Grell-Devenyi scheme; Grell and Devenyi 2002), which was found to be better for the cyclone case using the WRF model. The G-D scheme is an expansion from the Grell convective parameterization (Grell 1993) to include several alternative closure assumptions that are commonly used in convective parameterizations. The unique aspect of the $\mathrm{G}-\mathrm{D}$ scheme is that it uses 16 ensemble members derived from five popular closure assumptions to obtain an ensemble-mean realization at a time and location. These ensemble members are chosen because statistically they give a large spread in terms of accumulated convective rainfall. The details of how to determine the ensemble mean can be found in Grell and Devenyi (2002). The cloud microphysics scheme is WRF Single-Moment (WSM) 3-class simple ice scheme, which is a simple efficient scheme with ice and snow processes suitable for mesoscale grid sizes (Hong et al 1998, 2004). It replaces NCEP 3 scheme. The long-wave radiation parameterization is the Rapid Radiative Transfer Model (RRTM) scheme, which is an accurate scheme using look-up tables for efficiency accounts for multiple bands, trace gases, and microphysics species (Mlawer et al 1997). The short-wave radiation scheme is as per the Dudhia scheme, which allows simple downward integration for efficient cloud and clear-sky absorption and scattering (Dudhia 1989). The Planetary Boundary Layer (PBL) parameterization is the Yonsei University Scheme (YSU), which is the next generation MRF-PBL. It is non-local-K scheme with an explicit entrainment layer and parabolic $\mathrm{K}$ profile in unstable mixed layer (Skamarock et al 2005). Similar experiments in the operational mode are also conducted by integrating the WRF model at a relatively higher horizontal resolution $(20 \mathrm{~km})$ for $72 \mathrm{~h}$ with the same initial conditions of 28,29 , 30 and 1 May 2008 keeping all other options same as in the case of $27 \mathrm{~km}$ resolution.

\section{A brief description of the very severe cyclonic storm (VSCS) 'Nargis'}

Under the World Meteorological Organisation (WMO) definition about the tropical weather disturbances (table 1) has been adopted based on the maximum sustained wind speed when the system lies over sea area. Thus, when the maximum sustained wind exceeds 33 knots it is declared as a cyclone and when it exceeds 63 knots it is identified as very severe cyclonic storm (VSCS).

The system 'Nargis' initially appeared as a lowpressure area over southeast Bay of Bengal on 26 April and concentrated into a depression at 0300 UTC of 27 April. The observed track of 
the VSCS 'Nargis' is shown in figure 1. As seen from figure 1, the system slightly moved northwestwards and intensified into a depression and then into a cyclone at $00 \mathrm{UTC}$ of 28 April over southwest and adjoining southeast and westcentral Bay of Bengal about $550 \mathrm{~km}$ east of Chennai. The system remained practically stationary for some time and further intensified into an SCS at 09 UTC of 28 April and into a VSCS at 0300 UTC of 29 April over west central and adjoining southwest and southeast Bay of Bengal. The system moved slightly to the north and then eastwards for a period of about $30 \mathrm{~h}$ from $0600 \mathrm{UTC}$ of 1 May till 1500 UTC of May towards the Myanmar coast and crossed the coast of Myanmar between 1730 and $1930 \mathrm{~h}$ IST on 2 May 2008 as a 'VSCS' (figure 1). The intense cloud band associated with the system on 2 May at 06 UTC is shown in figure 2. Even after the landfall the system was maintaining its intensity as a VSCS for a period of about $12 \mathrm{~h}$. The VSCS 'Nargis' devastated large parts of

Table 1. Classifications of intensity of cyclonic systems over the north Indian Ocean.

\begin{tabular}{lc}
\hline Intensity of the system & $\begin{array}{c}\text { Maximum sustained } \\
\text { surface winds } \\
(\text { knots }) \text { at sea }\end{array}$ \\
\hline Low pressure area & $<1$ knot $\left.=0.5144 \mathrm{~ms}^{-1}\right)$ \\
Depression & $17-27$ \\
Deep depression (DD) & $28-33$ \\
Cyclonic storm (CS) & $34-47$ \\
Severe cyclonic storm (SCS) & $48-63$ \\
Very severe cyclonic & $64-119$ \\
storm (VSCS) & $>119$ \\
Super cyclonic storm & \\
\hline
\end{tabular}

the low-lying delta region of the Irrawaddy River. Winds exceeded $190 \mathrm{kmph}$ as the storm ripped through the Myanmar's biggest city Yangon (estimated population 6 million) for over more than ten hours. Homes were flattened, more sturdy structures damaged, trees uprooted and power lines downed. In rural parts of the country up to $95 \%$ of all homes were destroyed. In the history of Myanmar it had never faced such a disastrous weather system in past 40 years.

\section{Dynamical and thermodynamical features of VSCS 'Nargis'}

The genesis of such an intense system and forecasting of its unusual track is very challenging. The diagnostic study will give some characteristic features about the system associated with this unusual track. Before we discuss the results of WRF experiments the following dynamic and thermodynamic parameters are analysed to study the unusual movement of the VSCS 'Nargis'.

\subsection{Lower level (850hPa) vorticity and vorticity advection}

According to the atmospheric dynamics, the cyclone motion can be best represented by barotrophic vorticity equation in this form:

$$
\frac{\partial \xi}{\partial t}=-\vec{V} \cdot \nabla \xi-(\xi+f) \nabla \cdot \vec{V}+v \frac{\partial f}{\partial y}
$$

where ' $\xi$ ' is the relative vorticity, ' $\vec{V}$ ' is the horizontal wind vector, ' $v$ ' is the meridional wind

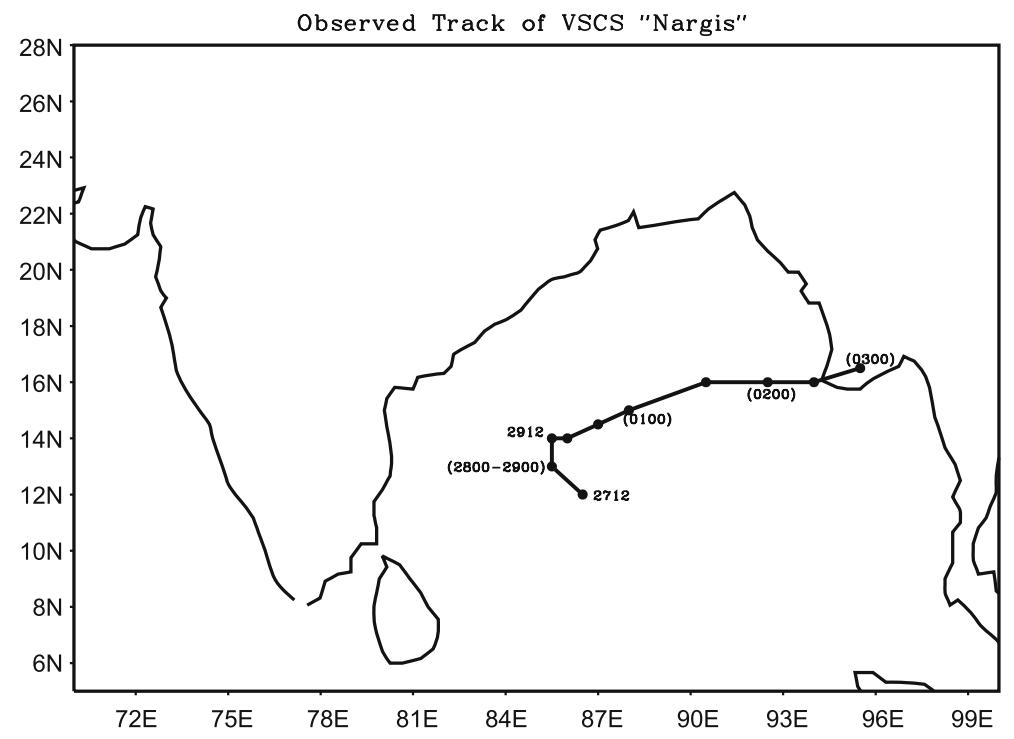

Figure 1. Twelve hourly track of the cyclone 'Nargis' (12 UTC of 27 April to 00 UTC of 3 May 2008). 


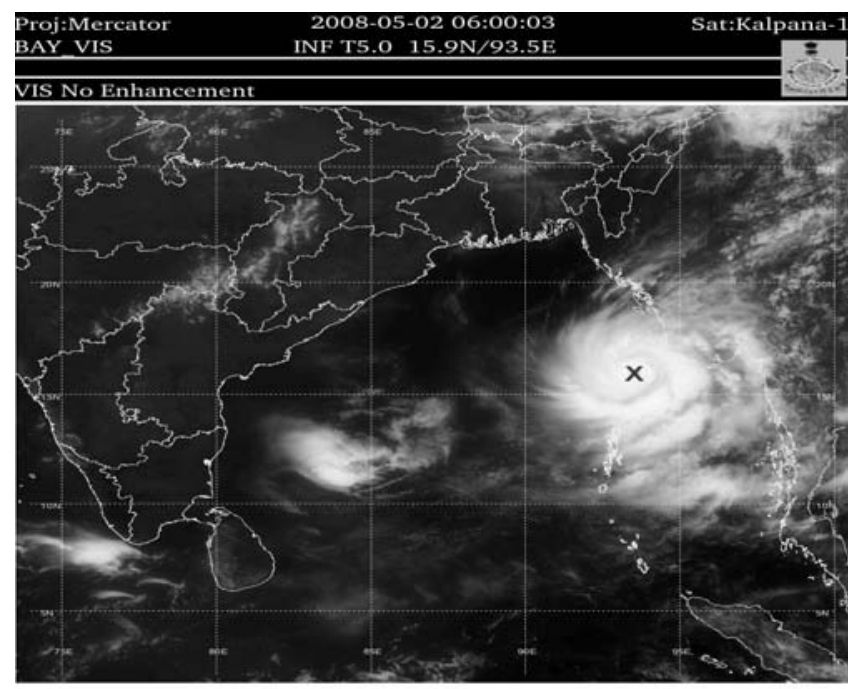

Figure 2. INSAT satellite picture of cyclone 'Nargis' at 0600 UTC of 2 May 2008.

component (positive towards north), and ' $f$ ' is the coriolis parameter. The maximum cyclonic vorticity is at the centre and decreases with increasing radius. Hence, if the cyclone is moving in a given direction, the local rate of change of cyclonic vorticity given by the left-hand side term of the above equation must also increase in the same direction. The $850 \mathrm{hPa}$ vorticity associated with the system from 28 April 00 UTC to 2 May $12 \mathrm{UTC}$ is shown in figure 3 . In the case of the VSCS 'Nargis', it was observed that vorticity increased in the easterly/eastnortheasterly direction suggesting recurvature and moved in easterly/east-northeasterly direction (figure 3). The vorticity maximum of the order of $60 \times 10^{-6} \mathrm{~s}^{-1}$ on 28 April was situated around $12.5^{\circ} \mathrm{N} / 85^{\circ} \mathrm{E}$ (figure $3 \mathrm{a}$ ) and this value gradually increases along the east/east-northeastwards direction on 2 May (figure $3 \mathrm{e}, \mathrm{f}$ ) to a value of the order of $210 \times 10^{-6} \mathrm{~s}^{-1}$.

The above vorticity change can only be achieved by the processes represented by the term in the right-hand side of the equation. The advection of relative vorticity $(-V \cdot \nabla \xi)$; where ' $\xi$ ' represents for relative vorticity governs the motion of the cyclone. The tropical cyclone generally responds like a protected symmetric vortex in a uniform noninteracting fluid flow and the flow simply advects the vortex along it. This fact was also evident in the case of cyclone 'Nargis', considering the relative vorticity advection (figure 4.) with east/northeast ward shift of region of negative vorticity advection particularly from 1 May onwards (figures $4 \mathrm{~d}$, e and $\mathrm{f}$ ). The relative vorticity advection suggested east/east-northeast movement of the embedded vortex.

\subsection{Upper level (200 hPa) winds}

The upper level winds at $200 \mathrm{hPa}$ during the period from 28 April to 3 May 2008 at 00 and 1200 UTC are shown in figure $5(\mathrm{a}-\mathrm{f})$ to highlight the role of steering current. As it is seen from figure 1 , the system was stationary for one day from $00 \mathrm{UTC}$ of 28 to 00 UTC of 29 April and moved in northerly direction during next $12 \mathrm{~h}$ (till $12 \mathrm{UTC}$ of 29) and subsequently recurved and moved in eastward direction. It is evident from the upper level flow that the system was under the influence of mainly the upper level southerly flow on 29 morning (figure 5b) and the recurvature of the system was associated with southerly/southwesterly flow from 30 April to 1 May (figure $5 \mathrm{c}$ and d). Thus, the recurvature of the system was associated with southerly/southwesterly wind at steering level ( $200 \mathrm{hPa}$ level) over the east-central Bay of Bengal and adjoining areas. The system was also under the influence of upper level anticyclonic flow situated on southeastern sector of the centre of the system on 30 April and 1 May (figure 5c and d) and the ridge line was quite south of the system position (figures $5 \mathrm{c}-\mathrm{f}$ ). This feature was helpful in recurving the system from its normal northwesterly track. As discussed earlier by Srinivasan and Ramamurthy (1973) the position of the ridge line at $200 \mathrm{hPa}$ is seen to govern the movement to a large extent. When the centre is near the ridge line, there is a northerly motion. Till the storm crosses the ridge line the movement continues in the northerly direction; when the centre is north of the ridge line as in the case of 'Nargis', in the majority of the cases a dominant easterly component of motion appears and thus, the system had a very long eastward movement.

\subsection{Sea surface temperature (SST) and convection (OLR)}

The SST was favourable $\left(29^{\circ} \mathrm{C}\right.$ or more $)$ over westcentral and adjoining east-central Bay of Bengal from 28 April onwards (figure not shown), which is a favourable condition for the intensification of the system. Further it may be seen that there was a warm pocket of SST anomalies (figure not shown) lies over west-central and adjoining eastcentral Bay of Bengal from 28 April onwards, which gradually concentrated over the Myanmar coast over east/east-northeast sector of the system centre from 30 April onwards. The presence of warm SST anomalies to the east/east-northeast sector of the system centre might have contributed to move the system towards the region of warm anomalies. Similar to the SST anomalies the minima in outgoing longwave radiation (OLR) anomaly (more negative values) also lay over the region to 
(a) $28 \mathrm{Apr}, 00$ UTC (VOR)
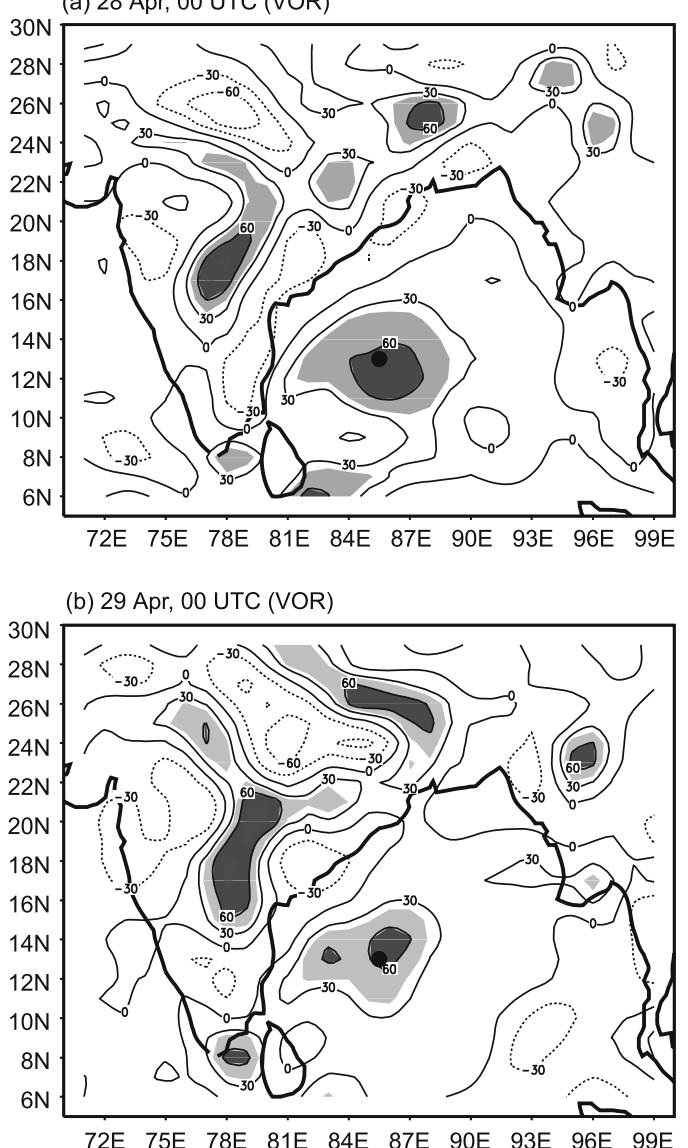

(c) $30 \mathrm{Apr}, 00$ UTC (VOR)

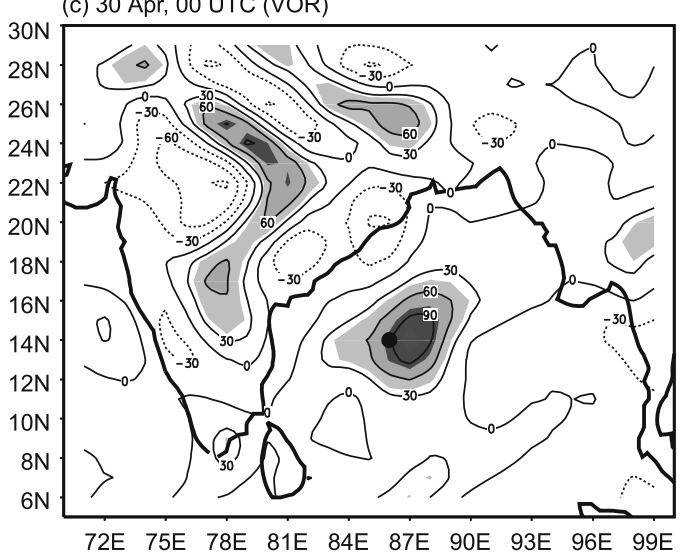

(d) 01 May, 00 UTC (VOR)
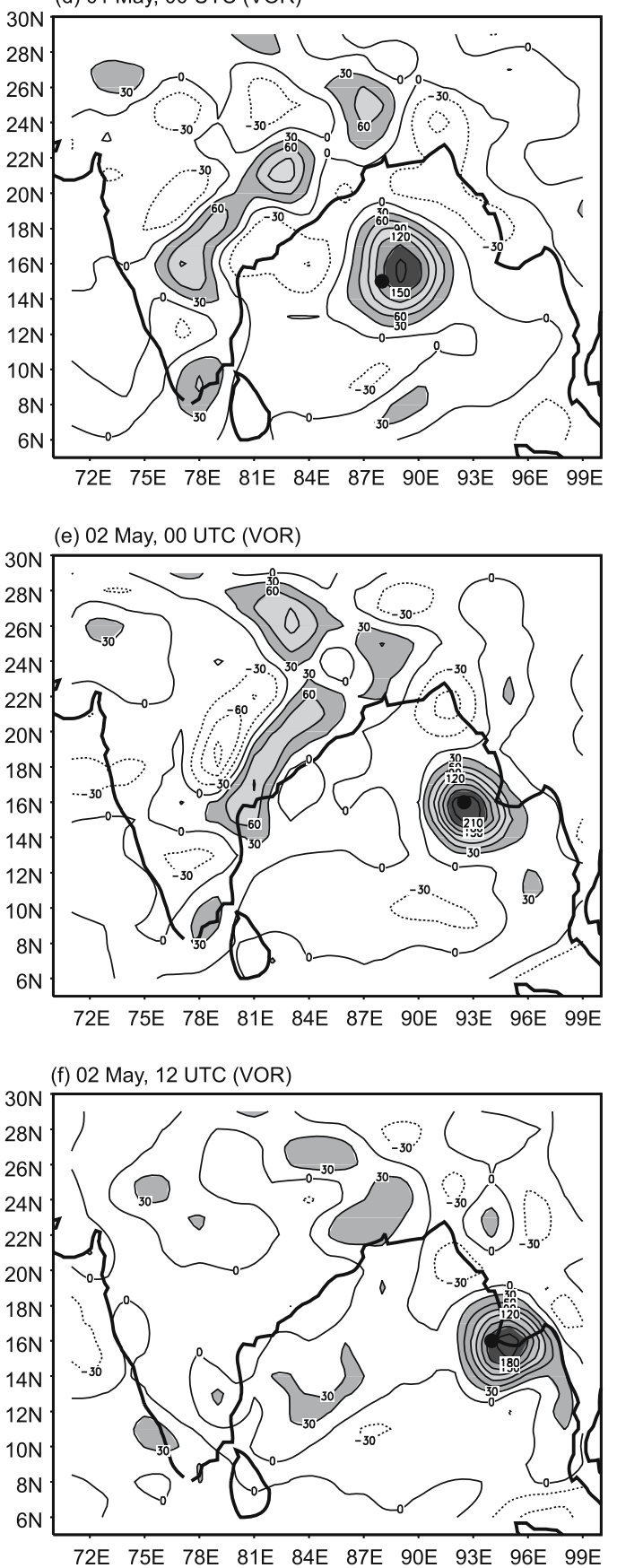

Figure 3. $850 \mathrm{hPa}$ relative vorticity in $\left(10^{-6} \mathrm{~s}^{-1}\right)$ during different stages of the cyclone Nargis from 28 April to 2 May 2008.

the east/northeast of the system centre from 28 April to 3 May (figure 6). The centre of OLR minima moved eastward from 29 April onwards. Richie et al (1993) have also shown that mesoscale convective systems are present in all stages of tropical cyclones besides enhancing the rainfall activity, they influence the tropical cyclone motion as well. In case of 'Nargis' from 30 April 2008 onwards the centre of OLR minima lies to the east of the cyclone centre and hence contributes to the eastward movement (figure $6 \mathrm{c}-6 \mathrm{f}$ ). As the
OLR minima correspond to the region of maximum convection, the monitoring of the convection centres (OLR minima) can give some useful guidance in predicting the movement of the cyclonic storm. However, to be used as an indicator for the movement of the system the resolution of the OLR data should be much higher than that used in the present case $\left(2.5^{\circ} \times 2.5^{\circ}\right.$ latitude-longitude grid $)$, which can fix the centre of convection anomalies more accurately with respect to the centre of the system. 
(a) $28 \mathrm{Apr}, 00$ UTC (VOR ADV)

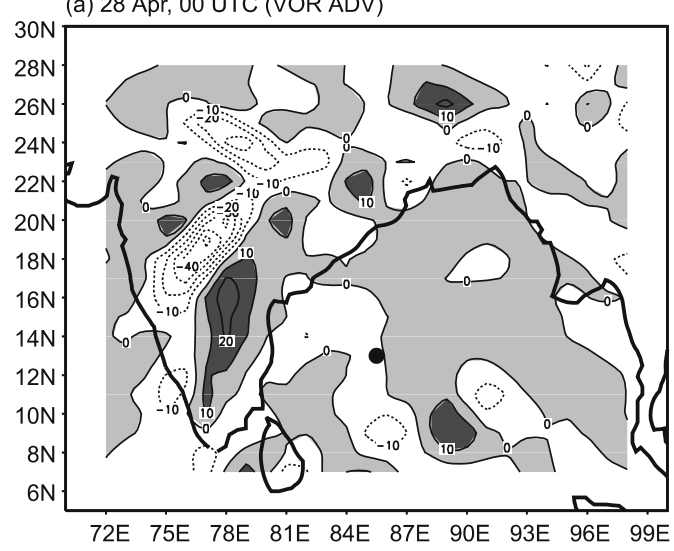

(b) 29 Apr, 00 UTC (VOR ADV)

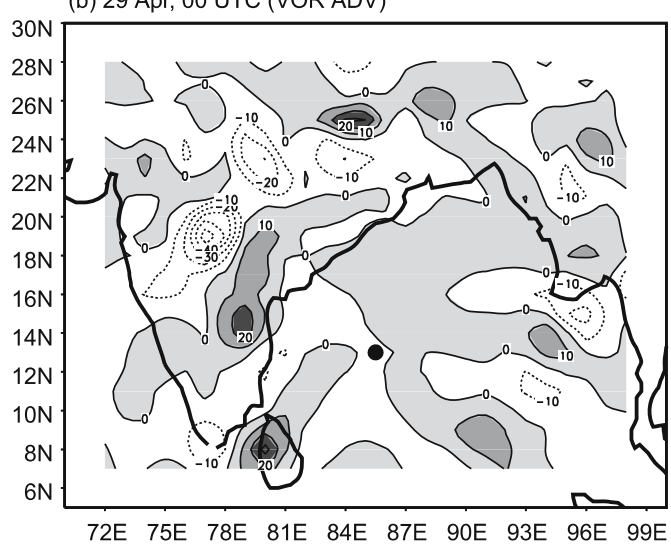

(c) $30 \mathrm{Apr}, 00$ UTC (VOR ADV)

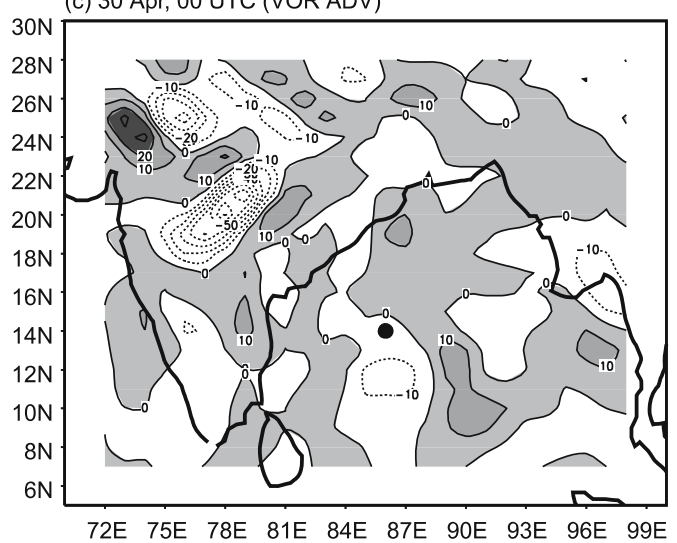

(d) 01 May, 00 UTC (VOR ADV)

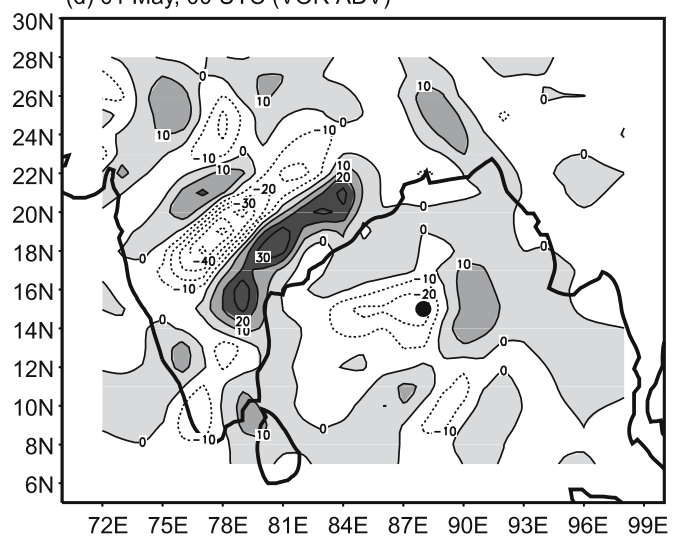

(e) 02 May, 00 UTC (VOR ADV)

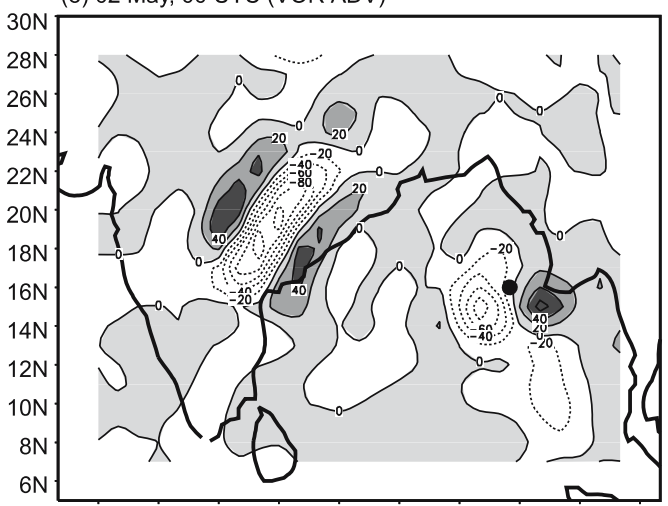

72E 75E 78E 81E 84E 87E 90E 93E 96E 99E

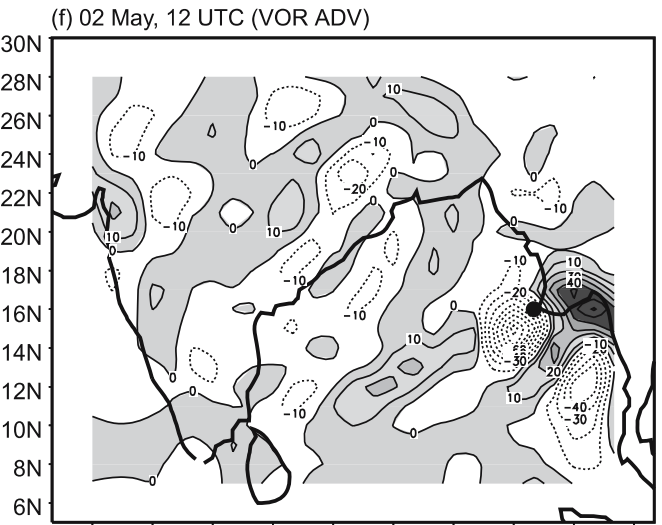

72E 75E 78E 81E 84E 87E 90E 93E 96E 99E

Figure 4. $850 \mathrm{hPa}$ horizontal vorticity advection (in $10^{-10} \mathrm{~s}^{-2}$ ) during different stages of recurved cyclone 'Nargis' during 2008.

\subsection{4-h pressure change}

The $24 \mathrm{~h}$ mean sea level pressure change for this cyclonic storm over the Indian region during 28 April to 3 May 2008 are analysed and presented in figure 7 . The $24 \mathrm{~h}$ pressure change indicates a large negative value in the eastern/northeastern sector (towards the Myanmar coast) of the system on 2 May with a value of the pressure fall of the order of $8 \mathrm{hPa}$ (figure $7 \mathrm{e}$ ). There is consistent $24 \mathrm{~h}$ pressure fall in the eastern/earth-northeastern direction from the system centre during 30 April to 3 May (figure 7c-7f). Thus, the VSCS 'Nargis' followed the direction of maximum negative isallobaric gradient and moved in the east/east-northeast direction as suggested in the cyclone manual (IMD 2003).

\subsection{Comparison of diagnostic parameters of 'Nargis' with that of past cyclones}

Some of the diagnostic parameters as discussed earlier in case of cyclone 'Nargis' is compared with that of previous two cyclones. The VSCS 
(a) $28 \mathrm{Apr}, 00 \mathrm{UTC}(200 \mathrm{hPa})$
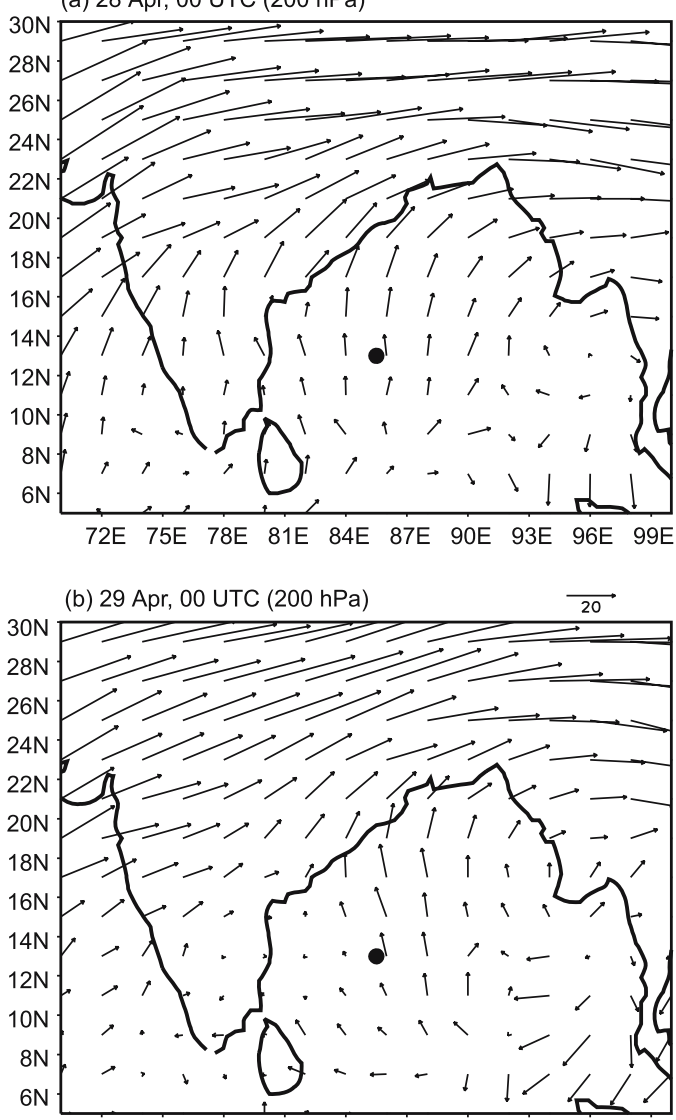

72E $75 \mathrm{E} \quad 78 \mathrm{E} \quad 81 \mathrm{E}$ 84E $87 \mathrm{E}$ 90E 93E 96E 99E

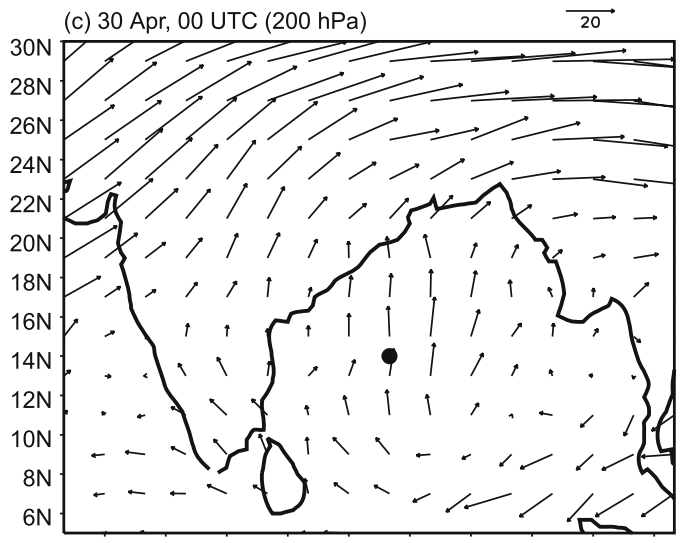

72E 75E 78E 81E 84E 87E 90E 93E 96E 99E

$\overrightarrow{20}$ (d) 01 May, 00 UTC (200 hPa)
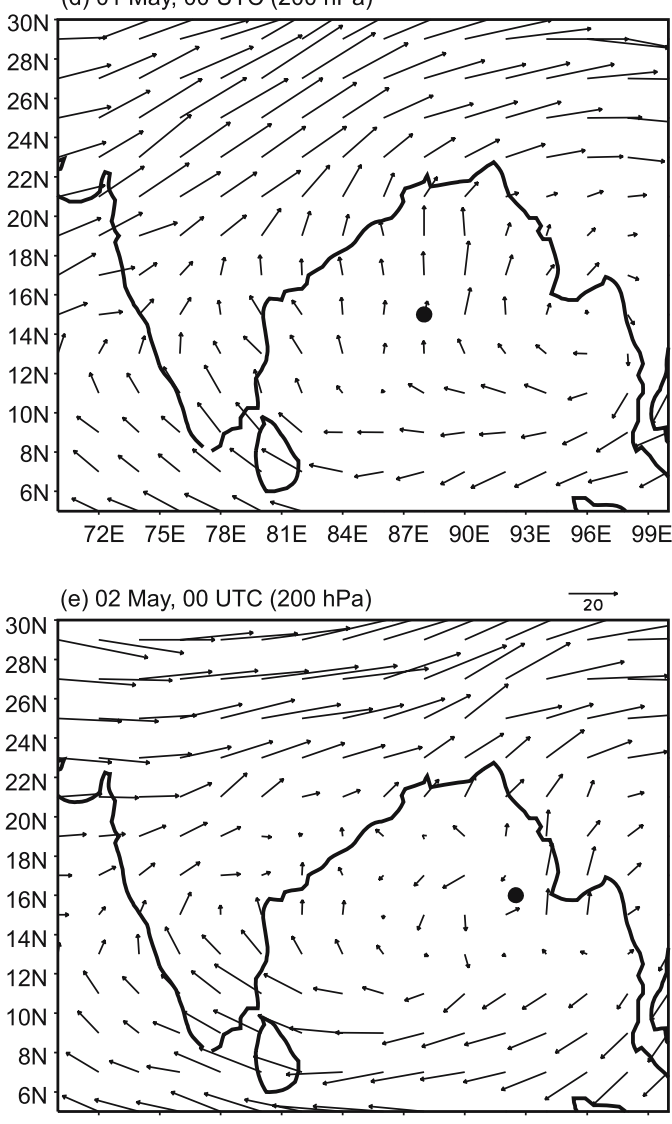

72E $75 \mathrm{E} \quad 78 \mathrm{E} \quad 81 \mathrm{E} \quad 84 \mathrm{E} \quad 87 \mathrm{E}$ 90E 93E 96E 99E

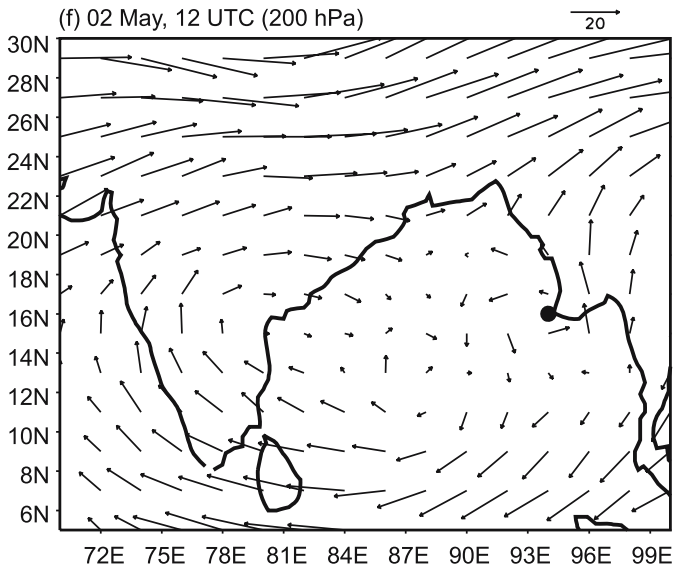

$\overrightarrow{20}$

Figure 5. The upper level winds over Indian region at $200 \mathrm{hPa}$ as per NCEP reanalysis at different times between 28 April and 2 May 2008.

'Nargis' was having $\mathrm{T}$ number 5 and it crossed the Myanmar coast between 12 and 14 UTC of 2 May 2008. The two cyclones considered for comparison are (a) the super cyclonic storm of 25-31 October 1999 that crossed the Orissa coast on 29 October between 0430 and 0630 UTC with T number of 7 and the other one is (b) the very severe cyclonic storm 'SIDR' over Bay of Bengal during 11-16 November 2007 that crossed the Bangladesh coast between 15 and 18 UTC of 15
November with $\mathrm{T}$ number of 6 . The low level relative vorticity, $24 \mathrm{~h}$ pressure change and the OLR anomalies on the respective date of crossing of coasts of these two cyclones are shown in figure 8 . The observed 24-hourly track of the super cyclone and that of the VSCS 'SIDR' is superposed in figure 8(a) (26-30 October 1999) and in figure 8(d) (12-16 November 2007) respectively in the vorticity maps. The low level vorticity in case of VSCS 'Nargis' on the day of crossing is of the order 
(a) $28 \mathrm{Apr}, 00$ UTC (OLRA)

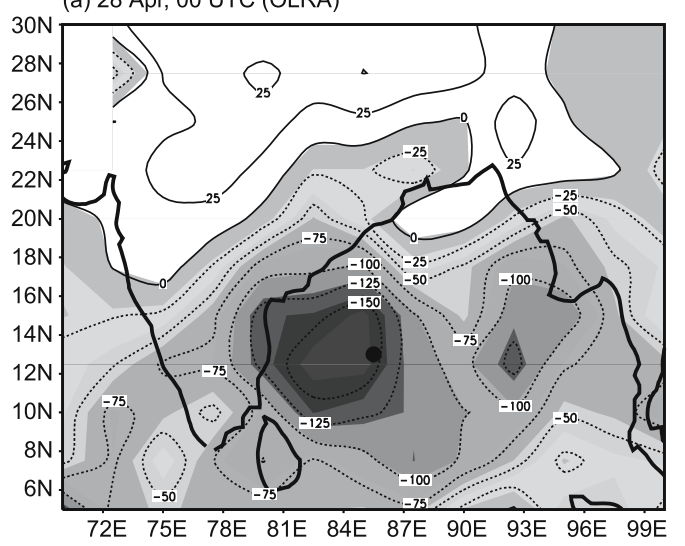

(b) 29 Apr, 00 UTC (OLRA)

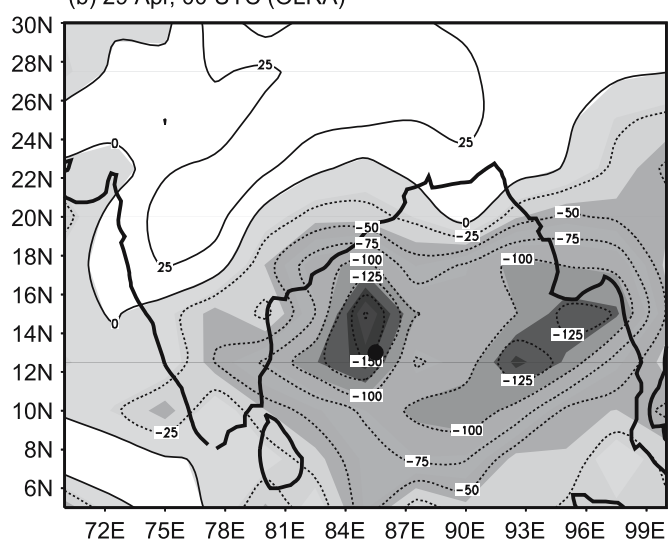

(c) $30 \mathrm{Apr}, 00$ UTC (OLRA)

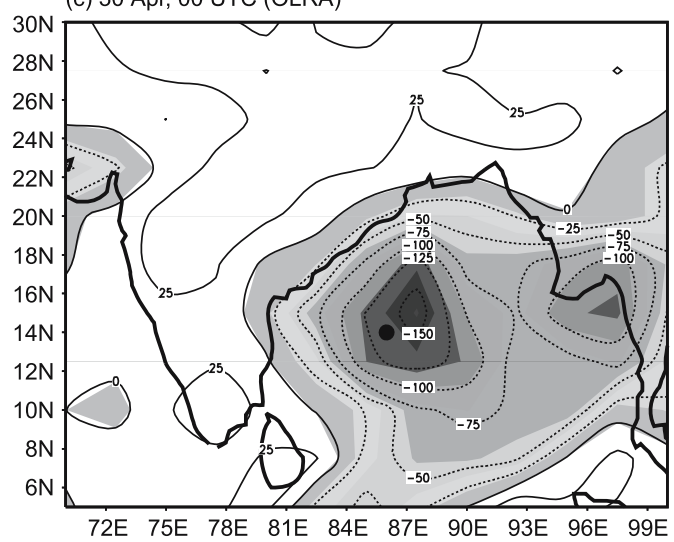

(d) 01 May, 00 UTC (OLRA)

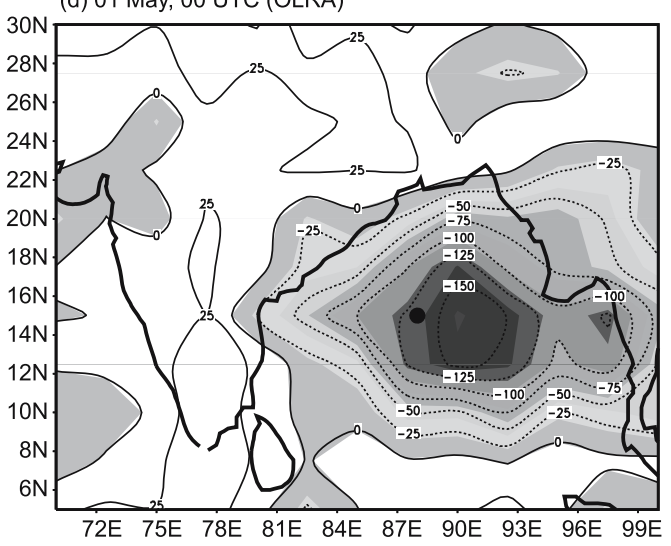

(e) 02 May, 00 UTC (OLRA)

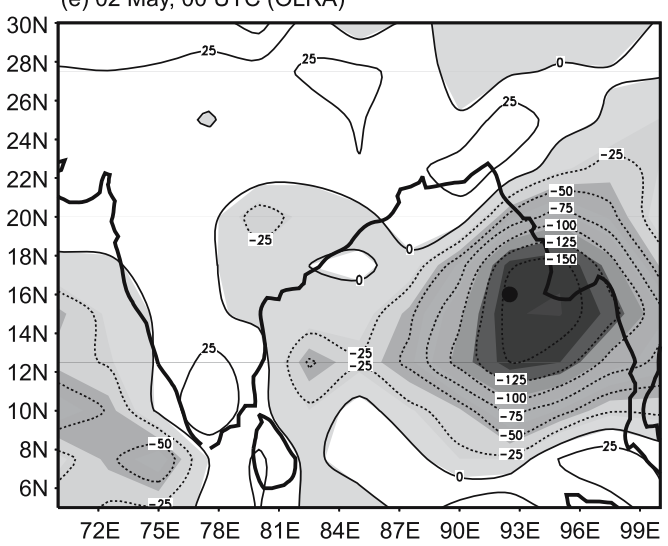

(f) 03 May, 00 UTC (OLRA)

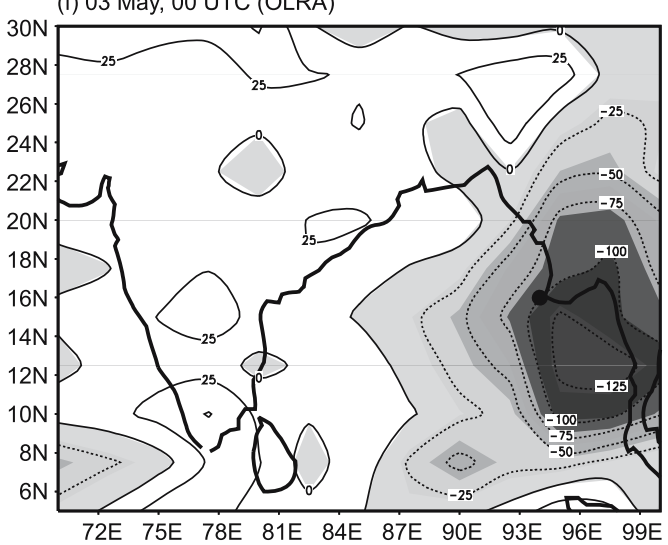

Figure 6. The OLR anomalies (watts $/ \mathrm{m}^{2}$ ) over Indian region as per NCEP reanalysis at 00 UTC of 28 April to 3 May 2008 (a)-(f).

of $210 \times 10^{-6} \mathrm{~s}^{-1}$ as shown in figure $3(\mathrm{e}$ and $\mathrm{f})$, which is of the same order in case of Orissa super cyclone as shown in figure $8(\mathrm{a})$. However, in case of the VSCS 'SIDR' the low-level vorticity is of the order of $150 \times 10^{-6} \mathrm{~s}^{-1}$ (figure $8 \mathrm{~d}$ ). The $24 \mathrm{~h}$ pressure fall as in case of VSCS 'Nargis' on 2 May (the date of crossing) is of the order of 7 to $8 \mathrm{hPa}$ to the east of the system (figure 7e), which is of the order of $4 \mathrm{hPa}$ on 3 May (figure $7 \mathrm{f}$ ), thus have very strong isallobaric gradient. In case of Orissa super cyclone and VSCS 'SIDR' the $24 \mathrm{~h}$ pressure fall is of the order of $4 \mathrm{hPa}$ in the forward direction of the system (figure $8 \mathrm{~b}$ and e). The faster east/east-northeastly movement of VSCS 'Nargis' on 1 May (day before the landfall) compared to that of other two cyclones cloud be due to the strong isallobaric gradient in case of 'Nargis' on 2 May. The convection anomalies as represented by the negative OLR anomalies are of the order of 150 watts $/ \mathrm{m}^{2}$ in case of VSCS 'Nargis', which is of the same order of that of Orissa super cyclone (figures 6e and 8c). However, the negative OLR 
(a) $28 \mathrm{Apr}, 00$ UTC (24hr MSLP)

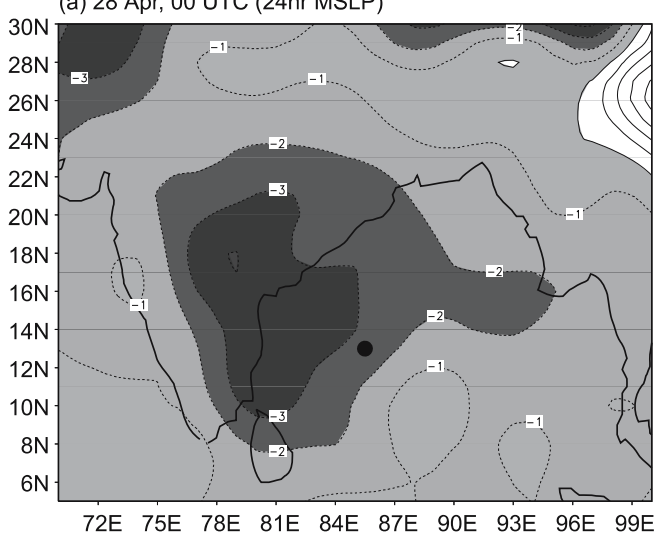

(b) $29 \mathrm{Apr}, 00$ UTC (24hr MSLP)
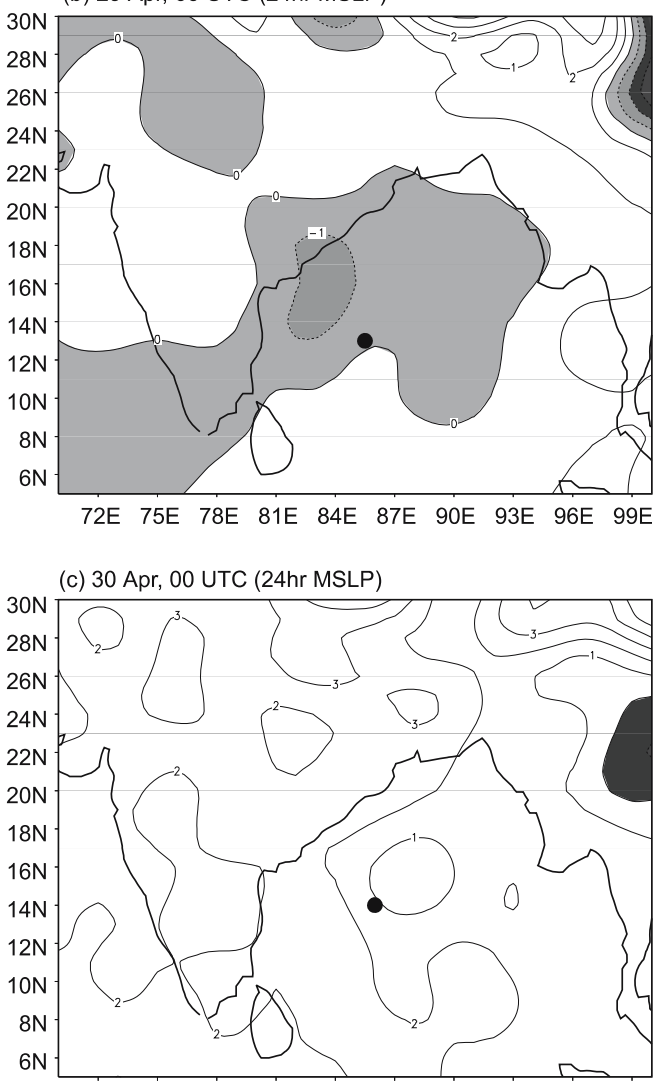

72E $75 \mathrm{E} \quad 78 \mathrm{E} \quad 81 \mathrm{E} \quad 84 \mathrm{E} \quad 87 \mathrm{E}$ 90E 93E 96E 99E (d) 01 May, 00 UTC (24hr MSLP)

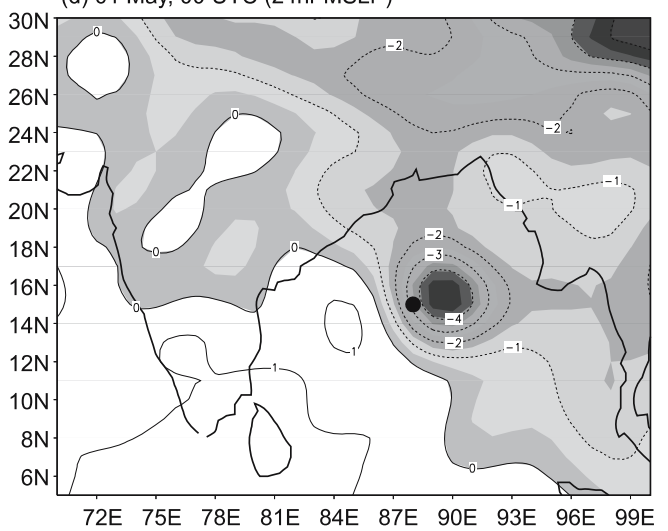

(e) 02 May, 00 UTC (24hr MSLP)

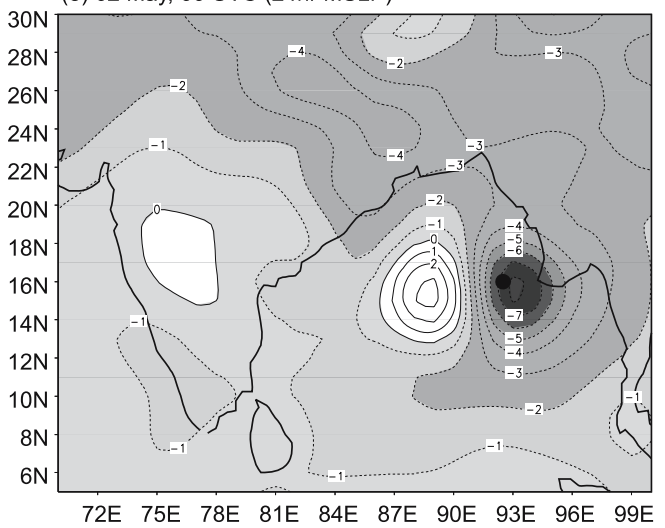

(f) 03 May, 00 UTC (24hr MSLP)

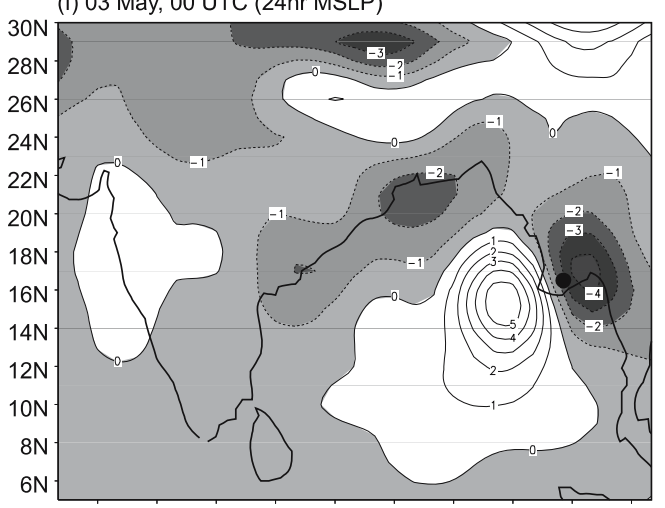

72E 75E 78E 81E 84E 87E 90E 93E 96E 99E

Figure 7. The $24 \mathrm{~h}$ mean sea level pressure change over Indian region at 00 UTC of 28 April to 3 May 2008 (a)-(f).

anomalies in case of VSCS 'SIDR' is of the order of 125 watts $/ \mathrm{m}^{2}$. On the other hand, the mean OLR (figure not shown) in case of 'Nargis' is lowest $\left(\approx 110\right.$ watts $\left./ \mathrm{m}^{2}\right)$ compared to that of Orissa super cyclone $\left(\approx 135\right.$ watts $\left./ \mathrm{m}^{2}\right)$ and the VSCS 'SIDR' $\left(\approx 150\right.$ watts $\left./ \mathrm{m}^{2}\right)$, which indicates that the very strong deep convection noticed in case of 'Nargis' just like that of the Orissa super cyclone. Thus, the vorticity and OLR anomalies indicate that the VSCS 'Nargis' and the Orissa super cyclone are of comparable characteristics and the VSCS 'SIDR' is found to be a relatively weaker system.

\section{Real time forecast of VSCS 'Nargis' using high resolution WRF model}

\subsection{Forecasts run of 'Nargis' with WRF model (27 km resolution)}

The real time track forecast of the VSCS 'Nargis' using WRF V2.2 model at $27 \mathrm{~km}$ resolution starting from the initial conditions of 28 April to 1 May at 00 UTC is shown in figure 9 and the corresponding Direct Positional Errors (DPE) are calculated as the geographical distance between 
(a) 29 Oct 1999 (850 hPa VOR)

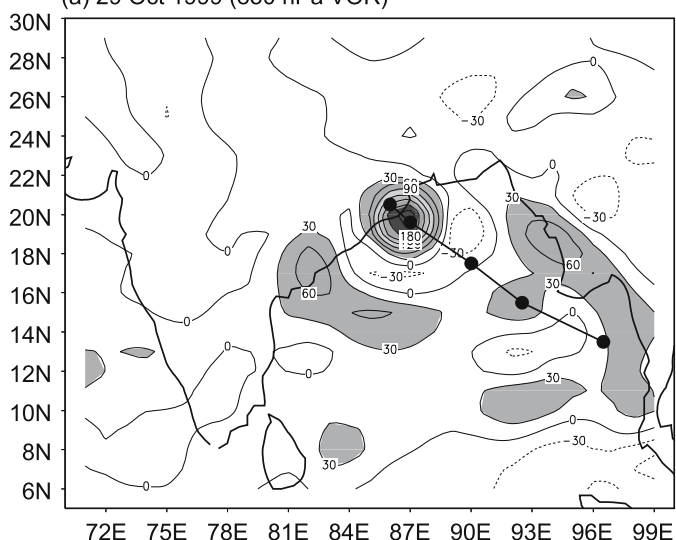

72E $75 \mathrm{E} \quad 78 \mathrm{E} \quad 81 \mathrm{E} \quad 84 \mathrm{E} \quad 87 \mathrm{E}$ 90E 93E 96E 99E

(b) 29 Oct 1999 (24hr MSLP)

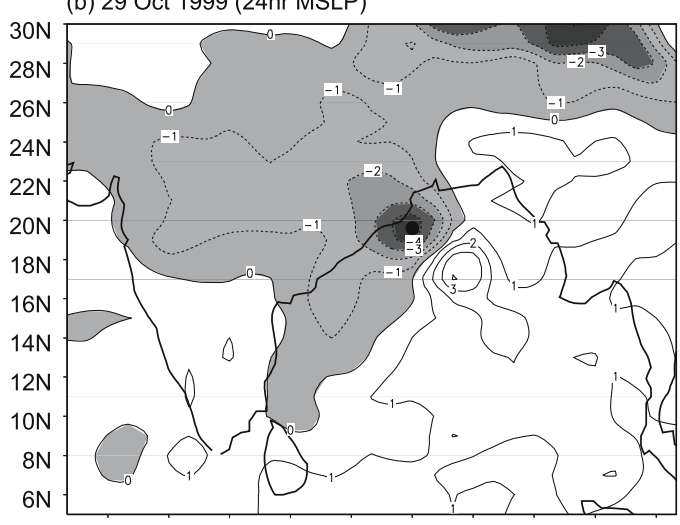

72E $75 \mathrm{E} \quad 78 \mathrm{E} \quad 81 \mathrm{E} \quad 84 \mathrm{E} \quad 87 \mathrm{E}$ 90E 93E 96E 99E

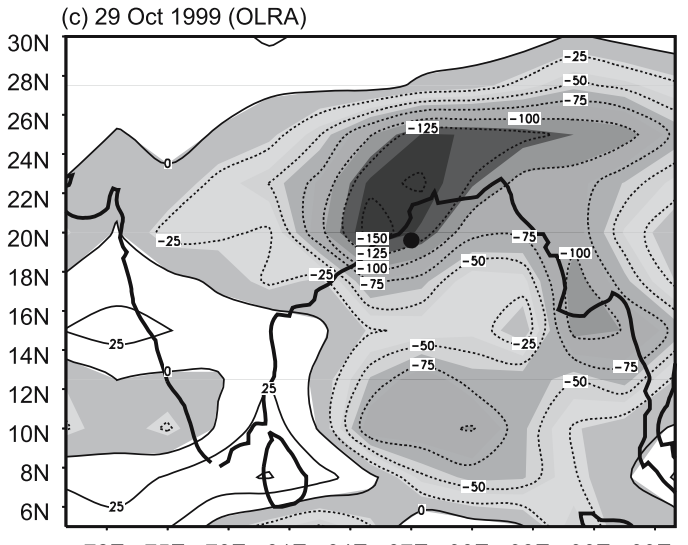

72E $75 \mathrm{E} \quad 78 \mathrm{E} \quad 81 \mathrm{E} \quad 84 \mathrm{E} \quad 87 \mathrm{E}$ 90E 93E $96 \mathrm{E}$ 99E (d) 15 Nov 2007 (850 hPa VOR)

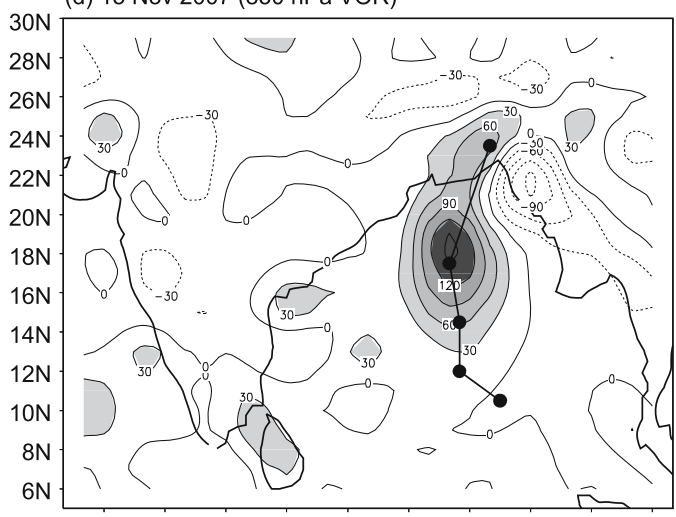

72E 75E 78E 81E 84E 87E 90E 93E 96E 99E

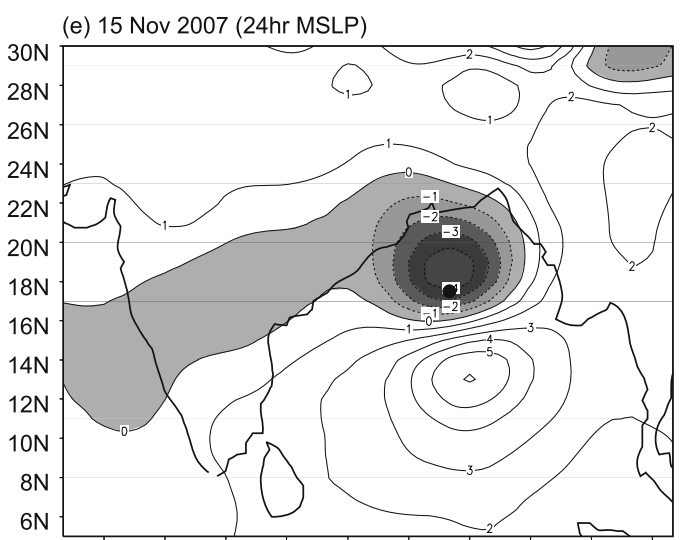

72E $75 \mathrm{E} \quad 78 \mathrm{E}$ 81E 84E 87E 90E 93E 96E 99E

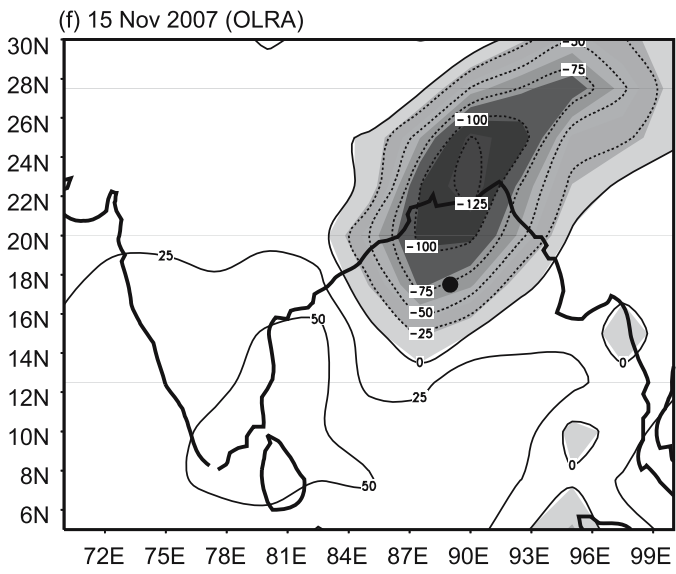

Figure 8. Parameters for Orissa super cyclone of October 1999 and that of cyclone 'SIDR' of November 2007. (a) $850 \mathrm{hPa}$ Relative vorticity in $\left(10^{-6} \mathrm{~s}^{-1}\right)$ on 29 October 1999, (b) $24 \mathrm{~h}$ pressure change on 29 October 1999, (c) OLR anomalies on 29 October 1999. (d) to (f) same as (a) to (c) but for the cyclone 'SIDR' on 15 November 2007. 24 hourly observed track from 26-30 October 1999 is superposed in (a) and that of 12-16 November 2007 in (b).

the observed and forecast point (table 2). Like the observed track of 'Nargis' as shown in figure 1, the WRF model forecast based on 28 April initial condition (figure 9) also clearly indicated that the system was not going to hit the Indian coast. The 12 hourly forecast track error of the cyclone as given in table 2 based on the initial date of 28 April is found to be with in the range of $235 \mathrm{~km}$ till $60 \mathrm{~h}$ of its forecast and the error increased to $349 \mathrm{~km}$ in $72 \mathrm{~h}$ as the forecast track showed northeasterly movement (figure 9) compared to the easterly track in the observed case (figure 1). Based on the initial condition of 29 April, when the system was relatively strong (severe cyclonic storm) the initial error is about $17 \mathrm{~km}$ (table 2) and the corresponding forecast errors also reduced substantially. The real time forecast using 29 April initial condition also shows no land fall till 00 UTC of 2 May. 


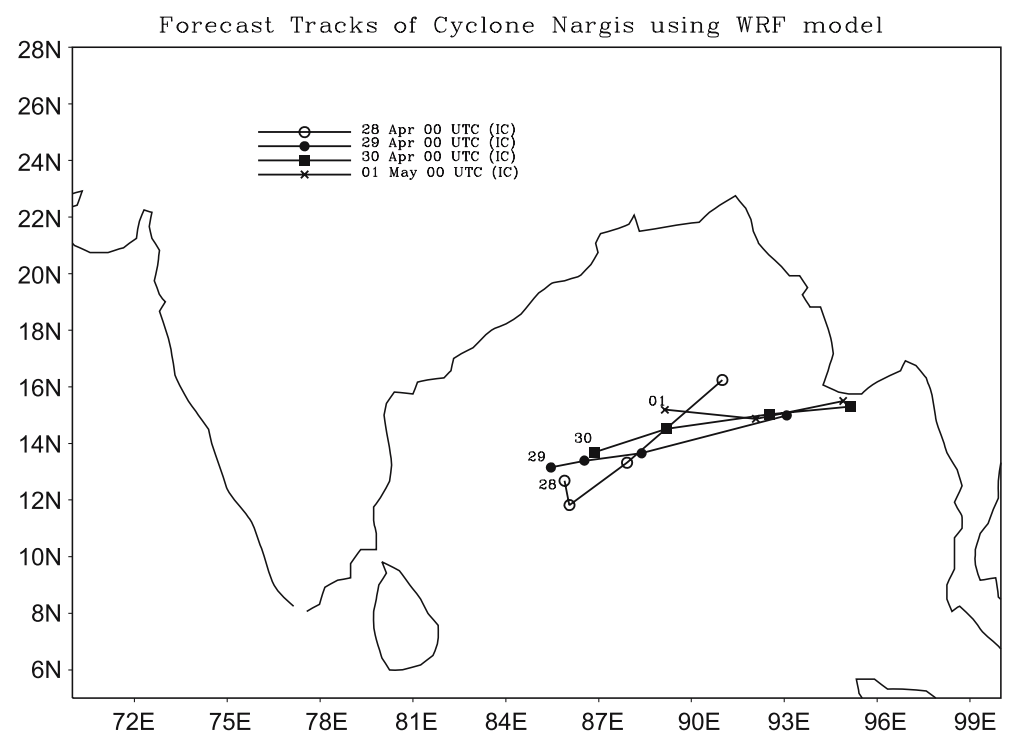

Figure 9. Initial and $24 \mathrm{~h}, 48 \mathrm{~h}$ and $72 \mathrm{~h}$ forecast positions of very severe cyclone 'Nargis' using WRF model at $27 \mathrm{~km}$ resolution with initial conditions of 28, 29, 30 April and 1 May 2008.

Table 2. Analysis errors, forecast errors and landfall errors of track forecast of cyclone 'Nargis' based on initial conditions of 28 April to 1 May 2008 using WRF model run at $27 \mathrm{~km}$ resolution.

\begin{tabular}{|c|c|c|c|c|c|}
\hline $\begin{array}{l}\text { Initial cond. } \rightarrow \\
\text { Errors } \downarrow\end{array}$ & $\begin{array}{l}28 \text { April } \\
\text { 00 UTC }\end{array}$ & $\begin{array}{l}29 \text { April } \\
\text { 00 UTC }\end{array}$ & $\begin{array}{l}30 \text { April } \\
\text { 00 UTC }\end{array}$ & $\begin{array}{l}1 \text { May } \\
00 \text { UTC }\end{array}$ & $\begin{array}{l}\text { Mean error } \\
\quad(\mathrm{km})\end{array}$ \\
\hline $00 \mathrm{~h}$ Anal error $(\mathrm{km})$ & 56 & 17 & 100 & 124 & 74 \\
\hline $12 \mathrm{~h}$ FC error $(\mathrm{km})$ & 101 & 138 & 138 & 89 & 116 \\
\hline $24 \mathrm{~h}$ FC error $(\mathrm{km})$ & 144 & 89 & 138 & 133 & 126 \\
\hline $36 \mathrm{~h}$ FC error $(\mathrm{km})$ & 233 & 131 & 153 & 140 & 164 \\
\hline $48 \mathrm{~h} \mathrm{FC}$ error $(\mathrm{km})$ & 220 & 155 & 108 & 148 & 158 \\
\hline $60 \mathrm{~h}$ FC error (km) & 227 & 158 & 96 & - & 160 \\
\hline $72 \mathrm{~h}$ FC error (km) & 349 & 128 & 97 & - & 191 \\
\hline Landfall error $(\mathrm{km})$ & No landfall & No landfall & 85 & 50 & - \\
\hline
\end{tabular}

However, the $72 \mathrm{~h}$ forecast position shows that the system was expected to hit the Myanmar coast as it followed the east/east-northeastward movement (figure 9) like that of observed track shown in figure 1. The forecast based on the initial condition of 30 April also shows east/east-northeastward movement of the cyclone till $72 \mathrm{~h}$ and was almost over the Myanmar coast in its $72 \mathrm{~h}$ forecast position (figure 9) and crossed the coast in its $78 \mathrm{~h}$ forecast position (figure not shown). Based on 30 April initial condition the forecast and observed tracks (figures 1 and 9) showed east/east-northeast movement of the system, although the forecast track showed slow movement compared to that of observed speed. The 12 hourly forecast error based on 30 April initial condition as given in table 2 is basically due to the slow movement of the system although it had a very similar track to that of the observed track. It is also indicated from figure 9 that the forecast tracks are improved with the initial conditions of 29 April to 1 May with landfall error of $85 \mathrm{~km}$ and $50 \mathrm{~km}$ based on the initial condition of 30 April and 1 May, respectively. The mean initial error and 12 hourly mean forecast errors found from the WRF model runs $(28,29$, 30 April and 1 May initial conditions) as given in table 2 is found to be less than $165 \mathrm{~km}$ till $60 \mathrm{~h}$, which became $191 \mathrm{~km}$ for $72 \mathrm{~h}$.

\subsection{Forecasts run of 'Nargis' with WRF model (20 km resolution)}

The WRF model is also run operationally in the hindcast mode for the VSCS 'Nargis' at a relatively higher resolution $(20 \mathrm{~km})$ starting from the initial conditions of 28 April to 1 May at 00 UTC and are given in figures $10-13$ respectively. The $850 \mathrm{hPa}$ wind for the analysis field along with the forecast winds valid at $24 \mathrm{~h}, 48 \mathrm{~h}$ and $72 \mathrm{~h}$ are shown starting from the initial condition of 28 April (figure 10) to 1 May (figure 13). The forecast track of 'Nargis' is also superposed in the diagram of 


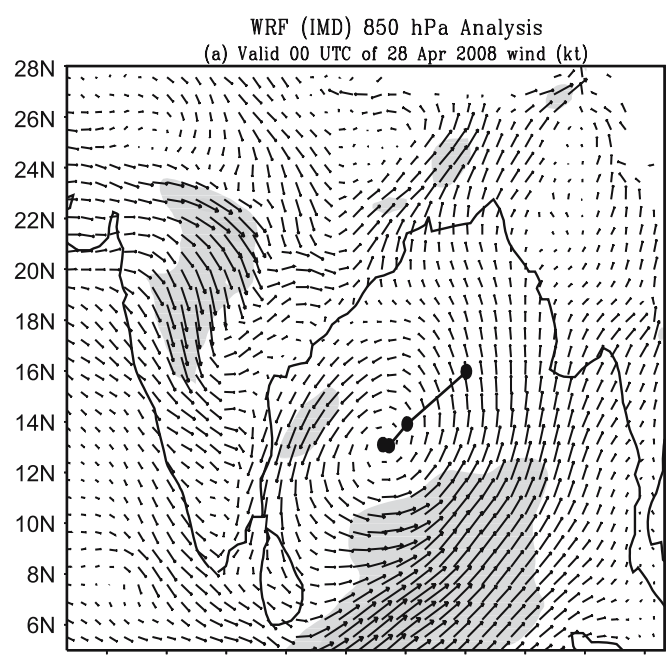

72E 75E 78E 81E 84E 87E 90E 93E 96E 99E $20 \quad 30 \quad 40 \quad 60 \quad \rightarrow \quad \longrightarrow$

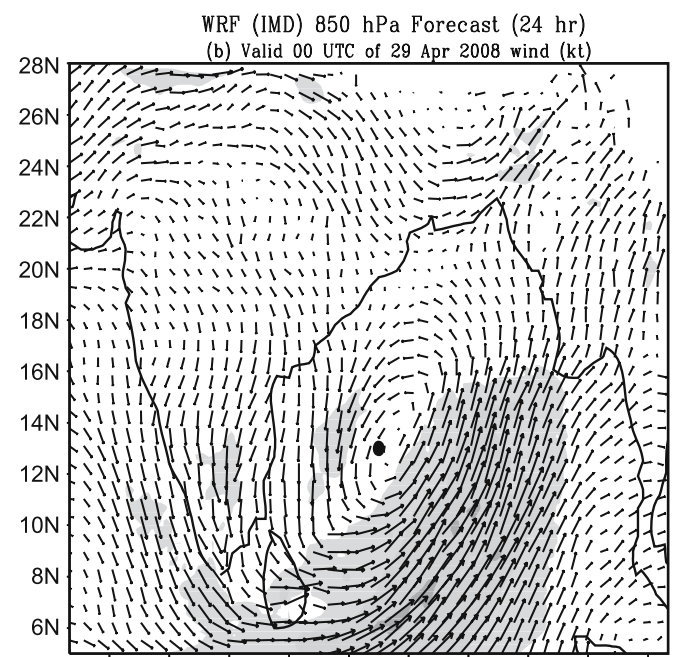

72E $75 \mathrm{E} \quad 78 \mathrm{E} \quad 81 \mathrm{E} \quad 84 \mathrm{E} \quad 87 \mathrm{E}$ 90E $93 \mathrm{E}$ 96E $99 \mathrm{E}$

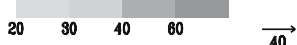

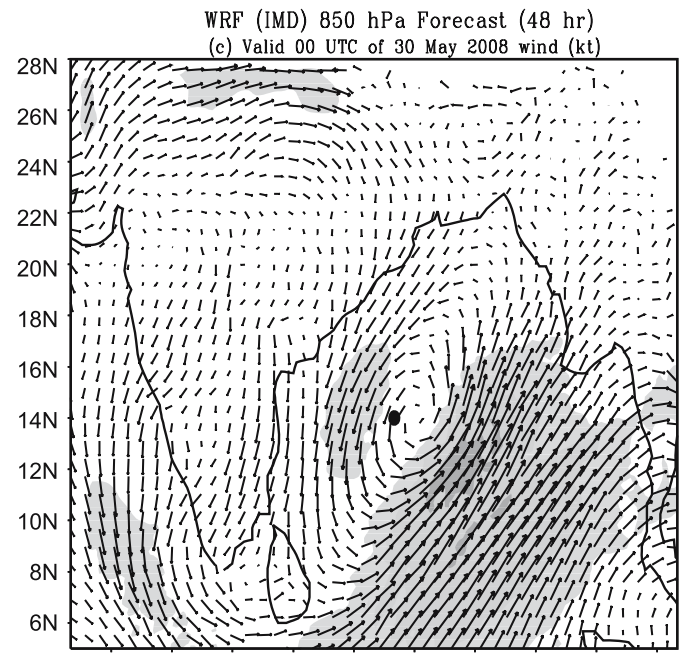

$72 \mathrm{E} 75 \mathrm{E}$ 78E 81E 84E 87E 90E 93E 96E 99E
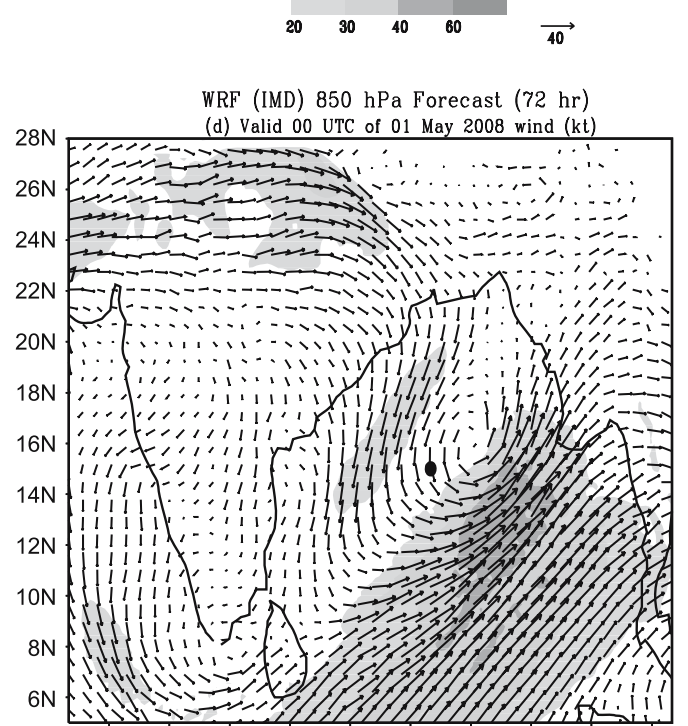

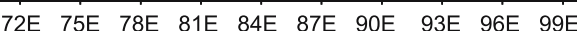

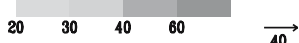

Figure 10. $850 \mathrm{hPa}$ wind of WRF analysis and 3 days forecast wind fields. (a) Analysis based on 28 April initial condition with $72 \mathrm{~h}$ forecast track, (b), (c) and (d) corresponds to $24 \mathrm{~h}, 48 \mathrm{~h}$ and $72 \mathrm{~h}$ forecast wind fields.

analysis field in figures 10(a), 11(a), 12(a) and 13(a) based on 28, 29, 30 April and 1 May initial conditions, respectively. In rest of the figures the corresponding observed position of the VSCS 'Nargis' is marked with a closed circle to compare with the forecast positions. Based on the 12 hourly forecast positions of all four days, the DPEs are calculated and are given in table 3 .

As it is seen from figure 10, the presence of a cyclonic vortices is represented in the initial model analysis field (figure 10a) although the exact position of the system is $35 \mathrm{~km}$ northeast of the analysis position and thus, has some analysis error as given in table 3 . Hence the initial genesis of the system was captured in the WRF analysis field on 28 April, when the system was over the southwest and adjoining southeast and west-central Bay of Bengal about $550 \mathrm{~km}$ east of Chennai. Like the observed track of 'Nargis' as shown in figure 1, the model forecast based on 28 April initial condition also clearly indicated that the system was not going to hit the Indian coast (figure 10a) and likely to move in northeasterly direction. It also indicates that there will be no landfall till 1 May 00 UTC. The forecast errors of the cyclone at $24 \mathrm{~h}$, $48 \mathrm{~h}$ and $72 \mathrm{~h}$ as given in table 3 based on the initial date of 28 April is found to be $73 \mathrm{~km}, 116 \mathrm{~km}$, and $244 \mathrm{~km}$ respectively. Based on 29 April initial condition when the system was relatively strong (severe cyclonic storm) the initial position as well as the forecast positions (figure 11) for $72 \mathrm{~h}$ forecast was very close to each other with initial error 

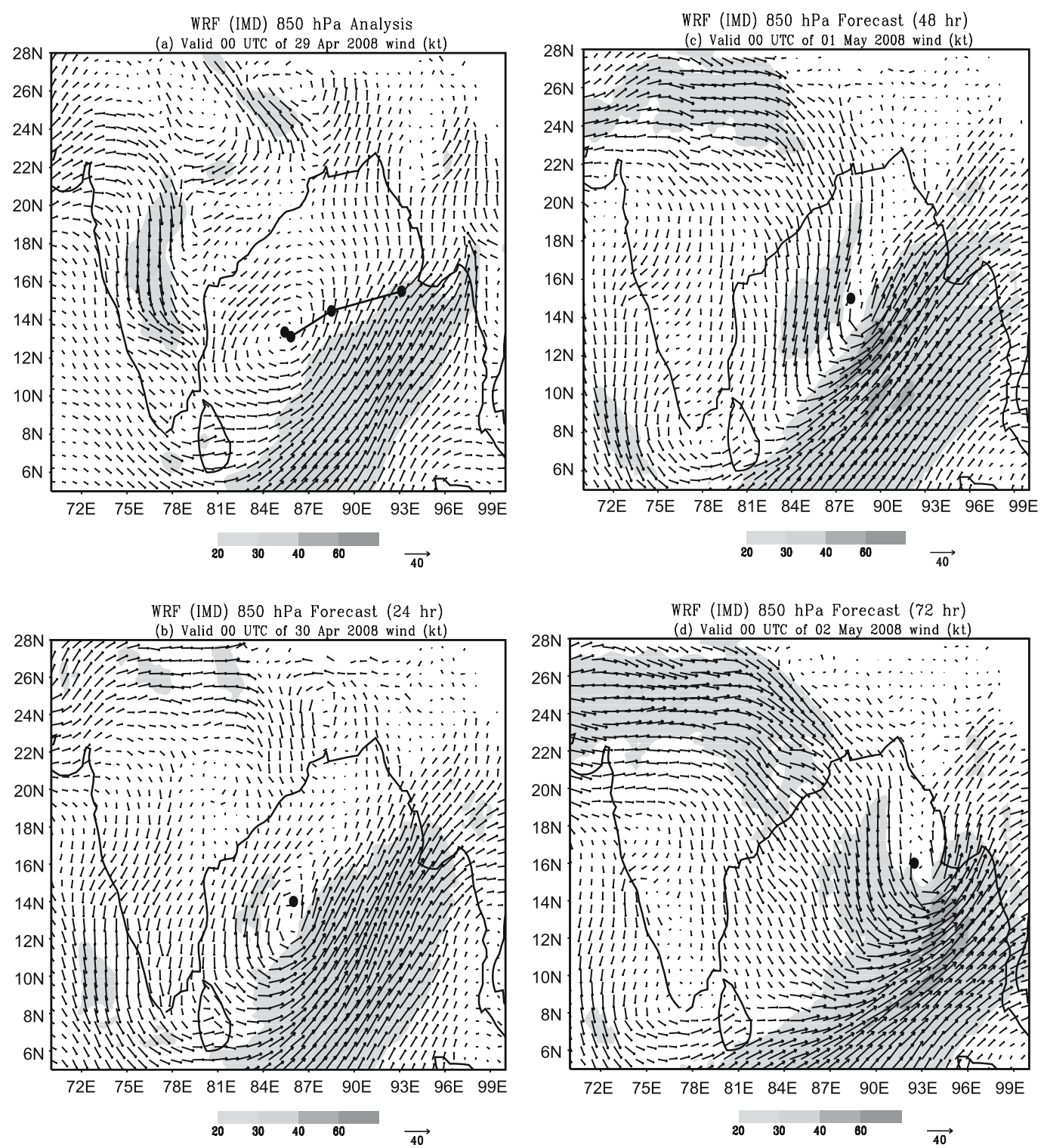

Figure 11. $850 \mathrm{hPa}$ wind of WRF analysis and 3 days forecast wind fields. (a) Analysis based on 29 April initial condition with $72 \mathrm{~h}$ track forecast. (b), (c) and (d) corresponds to $24 \mathrm{~h}, 48 \mathrm{~h}$ and $72 \mathrm{~h}$ forecast wind fields with indicated observed position.

of $41 \mathrm{~km}$ (figure $11 \mathrm{a}$ and table 3 ) and the forecast errors at $24 \mathrm{~h}, 48 \mathrm{~h}$ and $72 \mathrm{~h}$ are found to be $100 \mathrm{~km}, 80 \mathrm{~km}$ and $88 \mathrm{~km}$, respectively. The error during $24 \mathrm{~h}$ is found to be more than that during $48 \mathrm{~h}$ and $72 \mathrm{~h}$ basically due to very slow movement of the system during first $24 \mathrm{~h}$ in the forecast field compared to that of the observed track (figure 11b), whereas, the relatively faster movement during the subsequent hours as seen in the observed track in figure 1 is well captured in the forecast fields at $48 \mathrm{~h}$ and $72 \mathrm{~h}$ (figure $11 \mathrm{c}$ and 11d). The real time forecast using 29 April initial condition also shows no land fall till 00 UTC of 2 May, however, the $72 \mathrm{~h}$ forecast position shows that the system was close to the Myanmar coast as it followed the east/east-northeastward movement (figure 11) like that of the observed track shown in figure 1 . The forecast based on the initial condition of 30 April also shows east/eastnortheastward movement of the cyclone till $72 \mathrm{~h}$ and was close to the Myanmar coast in its $72 \mathrm{~h}$ forecast position (figure 12). Comparing the forecast track based on 30 April (figure 12a) with that of the observed track (figure 1) it is seen that both the tracks showed east/east-northeast movement of the system, although the forecast track showed slow movement compared to that of observed speed. The forecast errors at $24 \mathrm{~h}, 48 \mathrm{~h}$ and $72 \mathrm{~h}$ are found to be $53 \mathrm{~km}, 145 \mathrm{~km}$, and $200 \mathrm{~km}$ respectively, whereas the analysis error and $12 \mathrm{~h}$ forecast error are higher on this day $(93 \mathrm{~km}$ and $120 \mathrm{~km}$, respectively). It is basically due to deviation in the 

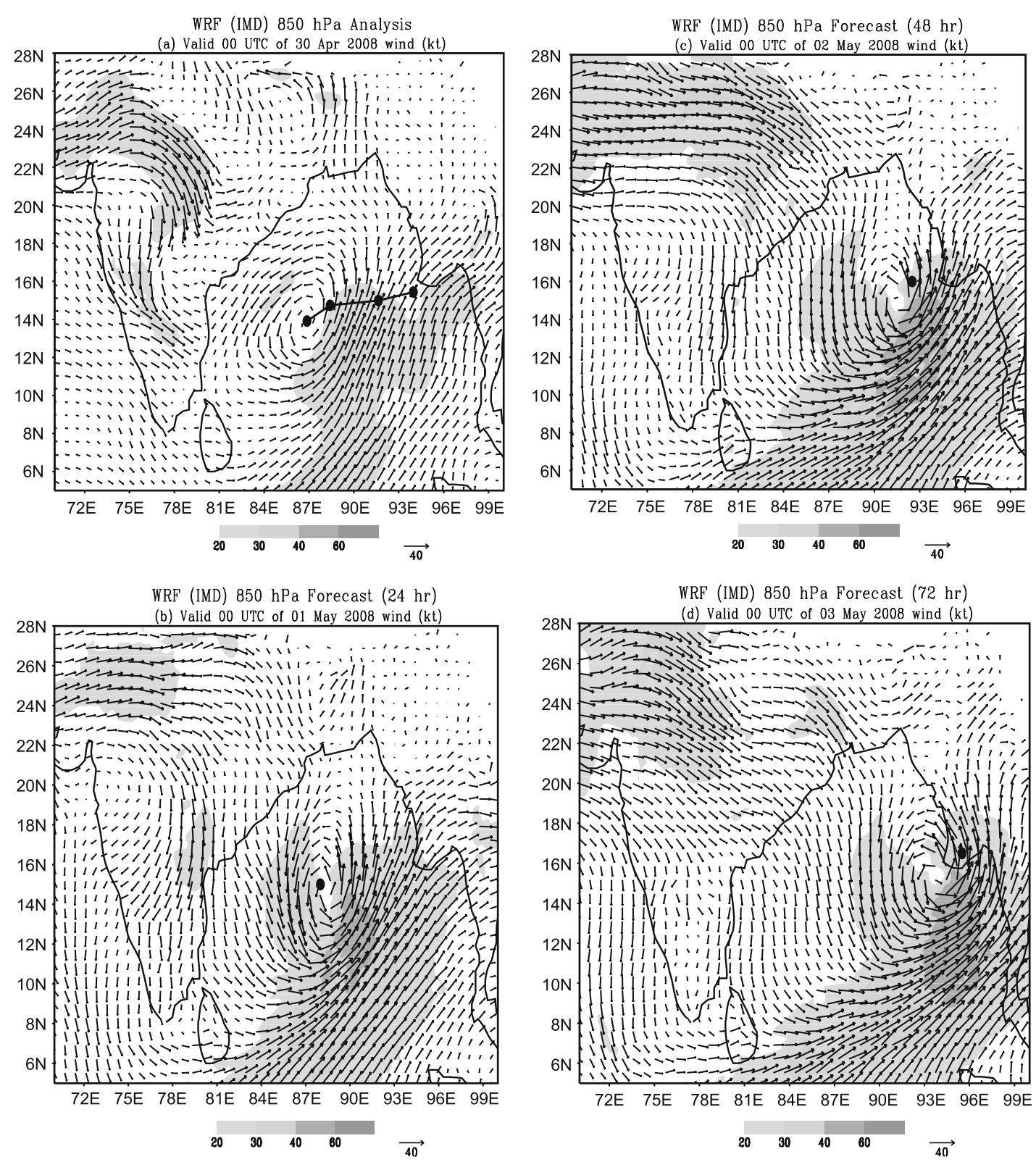

Figure 12. $850 \mathrm{hPa}$ wind of WRF analysis and 3 days forecast wind fields. (a) Analysis based on 30 April initial condition with $72 \mathrm{~h}$ track forecast. (b), (c) and (d) corresponds to $24 \mathrm{~h}, 48 \mathrm{~h}$ and $72 \mathrm{~h}$ forecast wind fields with indicated observed position.

initial position of WRF analysis field and subsequent slow movement of the system during next $12 \mathrm{~h}$ (figure not shown). The landfall error is about $30 \mathrm{~km}$ (figure 12 and table 3 ) with the WRF model run at $00 \mathrm{UTC}$ of 30 April (which is more than $60 \mathrm{~h}$ before the actual landfall time). Similarly, the initial condition of 1 May also showed eastward movement of the system towards the Myanmar coast like that of observed track (figure 13). The landfall error was about $40 \mathrm{~km}$ in this case. As seen from table 3 , though the landfall errors are very less $(30 \mathrm{~km}$ and $40 \mathrm{~km}$ ) based on 30 April and 1 May initial conditions the forecast error at $48 \mathrm{~h}$ is of the order of $145-150 \mathrm{~km}$, which is basically due to relatively slow movement of the systems in the forecast field compared to that of observed track as shown in figure 1 and as a result there was a delay in landfall timing by about $10 \mathrm{~h}$ in the forecast tracks. It is also noticed from tables 2 and 3 that with the increase in horizontal resolution from $27 \mathrm{~km}$ to $20 \mathrm{~km}$ the forecast errors on individual day and also the mean forecast errors from four days of integrations have been reduced. Thus, it is very clear that the advanced version WRF model in the real time forecast run had captured very well the movement of the VSCS 'Nargis' almost $72 \mathrm{~h}$ in advance with very less forecast error. 

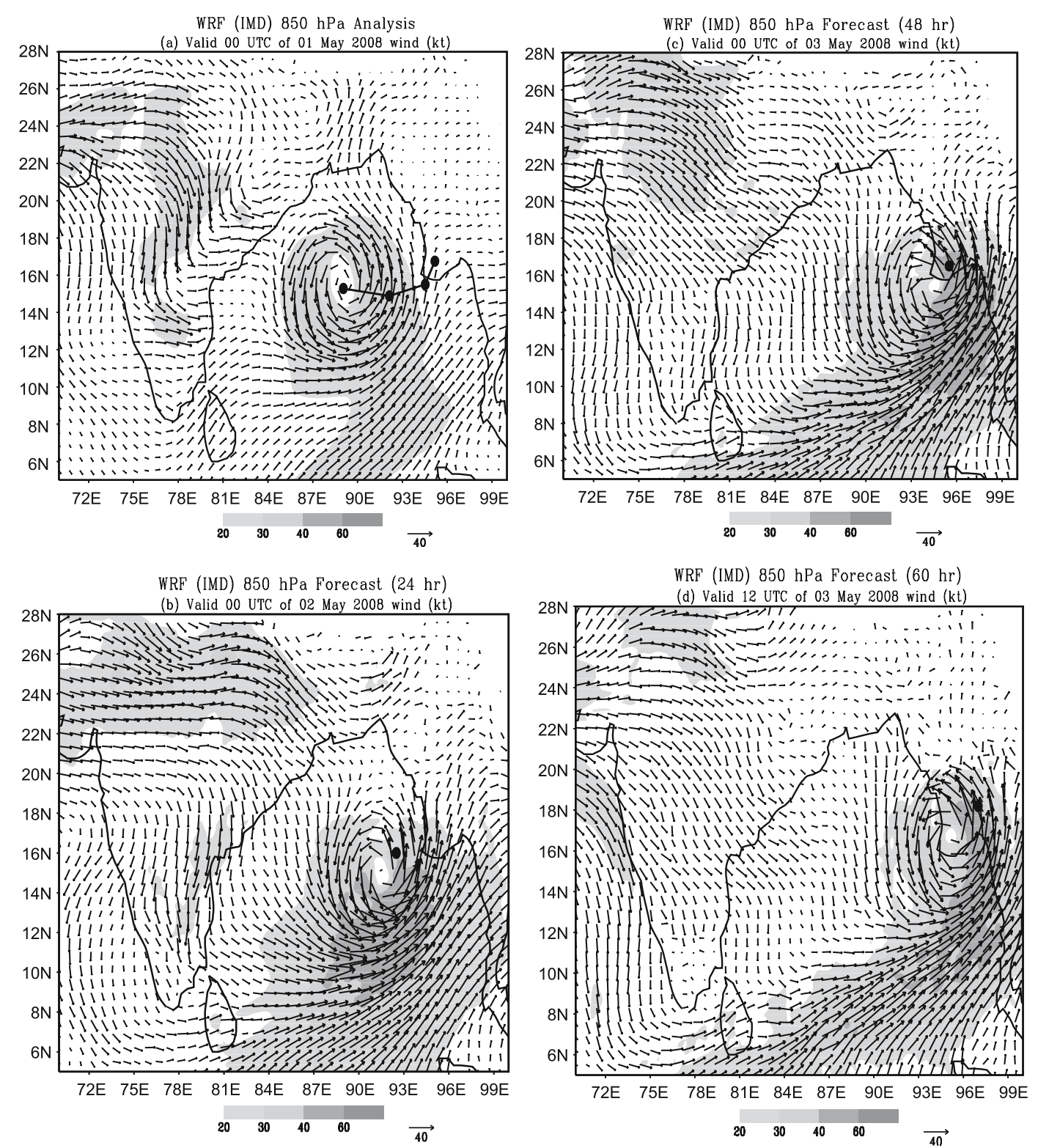

Figure 13. $850 \mathrm{hPa}$ wind of WRF analysis and 3 days forecast wind fields. (a) Analysis based on 1 May initial condition with $48 \mathrm{~h}$ track forecast. (b), (c) and (d) corresponds to $24 \mathrm{~h}, 48 \mathrm{~h}$ and $60 \mathrm{~h}$ forecast wind fields with indicated observed position.

\subsection{Analysis of diagnostic fields from the WRF model (20 km resolution) forecast}

As shown here the model has captured the eastward movement of cyclone reasonably well (figures 10-13). From the diagnostic analysis of the movement of VSCS 'Nargis' discussed earlier, it is observed that the recurvature of the system was associated with upper level southerly/ southwesterly wind at steering level $(200 \mathrm{hPa}$ level $)$ over the east central Bay of Bengal and the adjoining areas. From the $24 \mathrm{~h}$ mean sea level pressure change it is also noticed that the VSCS 'Nargis' followed the direction of maximum negative isallobaric gradient and moved in the east/east-northeast direction.
Thus, it will be very interesting to see whether the diagnostic features observed in the reanalysis is also simulated well in the model. For that purpose the upper level steering wind at $200 \mathrm{hPa}$ level and the MSLP change at different forecast hours in the forecast fields from WRF model are shown in figures 14 and 15, respectively. It is seen from figure 14 that the $48 \mathrm{~h}$ forecast valid on 30 April (figure 14a), that valid on 1 May (figure 14b) and the $72 \mathrm{~h}$ forecast that valid on 2 May (figure 14c) show the influence of upper-level southerly/southwesterly wind on cyclone, which indicated the easterly component of the movement of cyclone 'Nargis'. Figure 14(d-f) also indicates southerly/southwesterly forecast wind valid 
Table 3. Analysis errors, forecast errors and landfall errors of track forecast of cyclone 'Nargis' based on initial conditions of 28 April to 1 May 2008 using WRF model run at $20 \mathrm{~km}$ resolution.

\begin{tabular}{|c|c|c|c|c|c|}
\hline $\begin{array}{l}\text { Initial cond. } \rightarrow \\
\text { Errors } \downarrow\end{array}$ & $\begin{array}{l}28 \text { April } \\
\text { 00 UTC }\end{array}$ & $\begin{array}{l}29 \text { April } \\
\text { 00 UTC }\end{array}$ & $\begin{array}{l}30 \text { April } \\
\text { 00 UTC }\end{array}$ & $\begin{array}{l}1 \text { May } \\
00 \text { UTC }\end{array}$ & $\begin{array}{l}\text { Mean error } \\
\quad(\mathrm{km})\end{array}$ \\
\hline $00 \mathrm{~h}$ Anal error $(\mathrm{km})$ & 35 & 41 & 93 & 117 & 72 \\
\hline $12 \mathrm{~h}$ FC error $(\mathrm{km})$ & 84 & 81 & 120 & 91 & 94 \\
\hline $24 \mathrm{~h}$ FC error $(\mathrm{km})$ & 73 & 100 & 53 & 130 & 89 \\
\hline $36 \mathrm{~h}$ FC error $(\mathrm{km})$ & 150 & 106 & 155 & 130 & 135 \\
\hline $48 \mathrm{~h}$ FC error $(\mathrm{km})$ & 116 & 80 & 145 & 150 & 123 \\
\hline $60 \mathrm{~h}$ FC error $(\mathrm{km})$ & 154 & 148 & 188 & - & 163 \\
\hline $72 \mathrm{~h}$ FC error (km) & 244 & 88 & 200 & - & 177 \\
\hline Landfall error $(\mathrm{km})$ & No landfall & No landfall & 30 & 40 & - \\
\hline
\end{tabular}

for 1 and 2 May, which can be responsible for the eastward movement of the cyclone noticed in the model forecast. Just like in case of observation field (figure 5) the forecast fields also show presence of anticyclone circulation to the south of the system. Similarly, the forecast MSLP change (figure 15a15f) at different hours also indicate pressure fall (of the order of more than $4 \mathrm{hPa}$ ) to the east of the system and hence the cyclone followed the direction of maximum negative isallobaric gradient and moved in eastward direction.

\subsection{Discussions of the results}

Over the years there have been improvement in the track forecast of tropical cyclone by numerical models. It may be mentioned that during the past three decades, forecast track errors from numerical prediction systems have decreased by approximately $25 \%$ at $24 \mathrm{~h}, 35 \%$ at $48 \mathrm{~h}$ and $50 \%$ at $72 \mathrm{~h}$ in the Atlantic basin (McAdie and Lawrence 2000). The 12 hourly mean forecast track error from the four days run (28 April to 1 May) as shown in tables 2 and 3 are much less than the mean forecast errors over the north Indian Ocean by different models (Gupta 2006). As summarized in a recent article by Gupta (2006), the mean forecast errors by Quasi-Lagrangian Model (QLM) run at $40 \mathrm{~km}$ resolution for 20 tropical cyclone cases over north Indian Ocean region for the seven-year period (1998-2004) is found to be $140 \mathrm{~km}$ for $24 \mathrm{~h}$, $202 \mathrm{~km}$ in $48 \mathrm{~h}$ and $315 \mathrm{~km}$ for $72 \mathrm{~h}$. The mean track forecast errors from the UK Met Office (UKMO) global model for three seasons prior to northern summer 2002 for the north Indian Ocean is found to be $130 \mathrm{~km}$ ( 54 cases) for $24 \mathrm{~h}, 220 \mathrm{~km}$ (36 cases) for $48 \mathrm{~h}, 313 \mathrm{~km}$ (20 cases) for $72 \mathrm{~h}, 305 \mathrm{~km}$ (11 cases) for $96 \mathrm{~h}$ and $278 \mathrm{~km}$ (6 cases) for $120 \mathrm{~h}$ (Gupta 2006). Similarly the mean forecast error from the NCMRWF T-80 global model from the six tropical cyclones of north Indian Ocean during 1995-96 using the bogus vortex in the initial field is found to be $132 \mathrm{~km}$ for $24 \mathrm{~h}, 418 \mathrm{~km}$ for $48 \mathrm{~h}$ and $594 \mathrm{~km}$ for $72 \mathrm{~h}$ (Gupta 2006). Although the mean forecast errors obtained in case of the VSCS 'Nargis' in WRF model are much less as compared to the mean forecast error from QLM and other global models, a detailed statistics of WRF model will have to be considered by taking more number of cases to prepare the error statistics to make a proper comparison. The different physics and dynamic options available in the advanced version of WRF model can be considered for the preparation of detailed statistics, which is planned to be carried out in a separate study.

In the case of VSCS 'Nargis' the different numerical models have performed differently in the real time. As seen from the verification of track forecast by the UK Met Office global model for the VSCS 'Nargis' (obtained from forecast verification of tropical cyclone track forecast from UKMO site http://www.metoffice.gov.uk/ weather/tropicalcyclone/tctracks) the 120-hour prediction of landfall was good, whereas the 96-hour forecast was poorer. This pattern was repeated for shorter lead time forecasts. The model had a right of track bias, which meant that many forecast tracks took 'Nargis' south of the Irrawaddy Delta of Burma. However, 24-36 h ahead of landfall, the forecasts were good. The landfall error as estimated from the forecast charts of UKMO model based on the initial conditions of 30 April ( $60 \mathrm{~h}$ before the landfall) and 1 May (36 h before the landfall) was found to be around $150 \mathrm{~km}$ and $110 \mathrm{~km}$, respectively with a time delay of about $4-5 \mathrm{~h}$. The performance of ECMWF global model for the case of VSCS 'Nargis' was much closer to the observed track with estimated landfall errors of less than $50 \mathrm{~km}$ based on the initial conditions of 30 April (60 h before the landfall) and 1 May (36 h before the landfall) with an estimated $7 \mathrm{~h}$ early landfall. The QLM model run operationally in IMD showed large error in case of VSCS 'Nargis' with landfall error of more than $300 \mathrm{~km}$ based on initial conditions of 30 April and 1 May $(60 \mathrm{~h}$ and $36 \mathrm{~h}$ 
(a) $28 \mathrm{Apr}(48 \mathrm{hr} 200 \mathrm{hPo}$ wind)

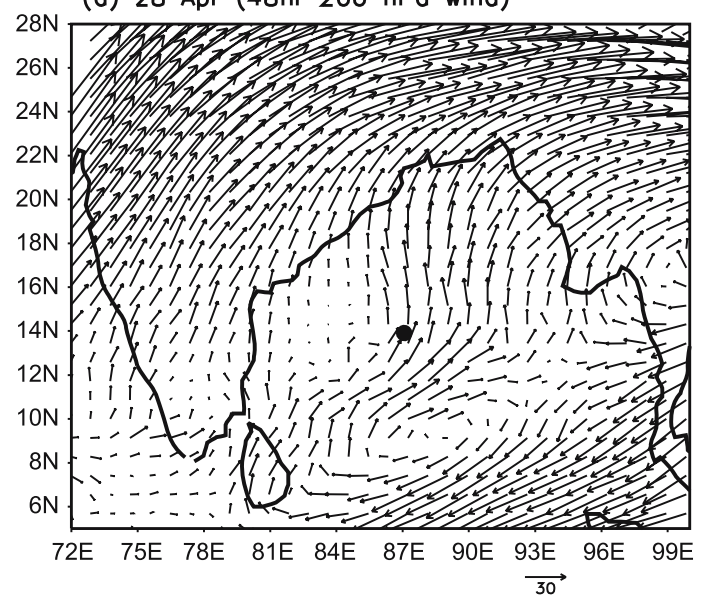

(b) $29 \mathrm{Apr}$ (48hr $200 \mathrm{hPo}$ wind)

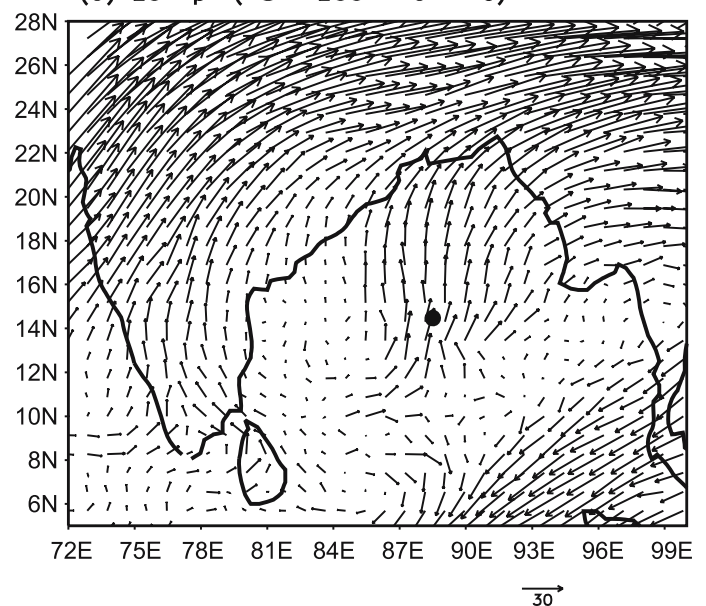

(c) $29 \mathrm{Apr}(72 \mathrm{hr} 200 \mathrm{hPa}$ wind)

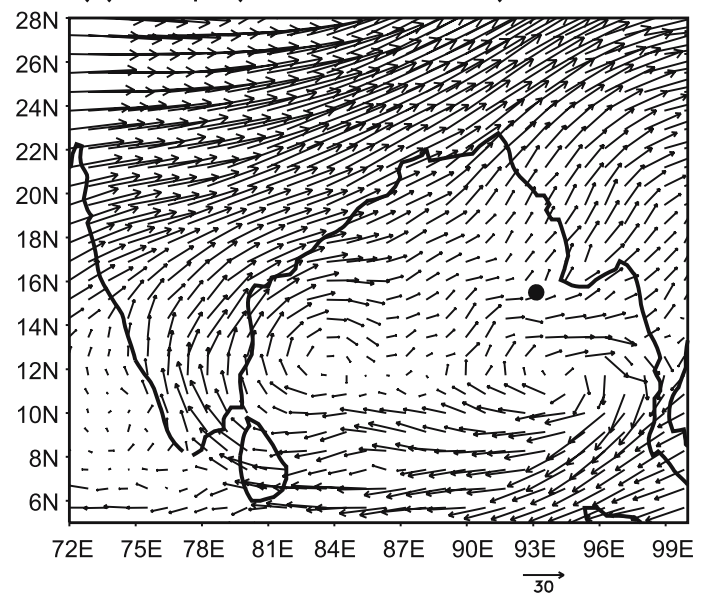

(d) $30 \mathrm{Apr}$ (24hr $200 \mathrm{hPo}$ wind)

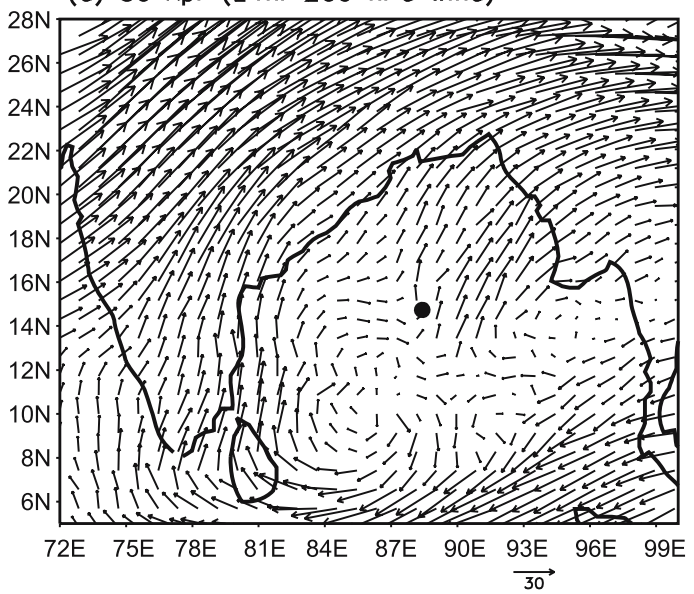

(e) $30 \mathrm{Apr}(48 \mathrm{hr} 200 \mathrm{hPo}$ wind)

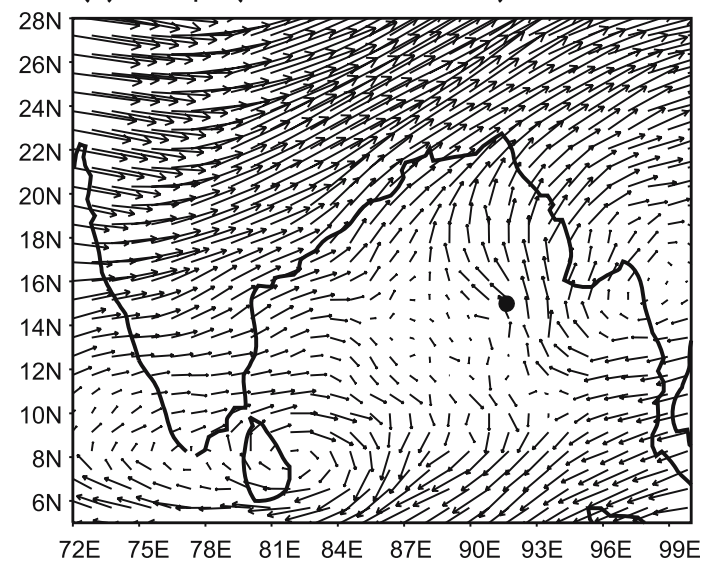

$\overrightarrow{30}$

(f) 01 Moy ( $24 \mathrm{hr} 200 \mathrm{hPa}$ wind)

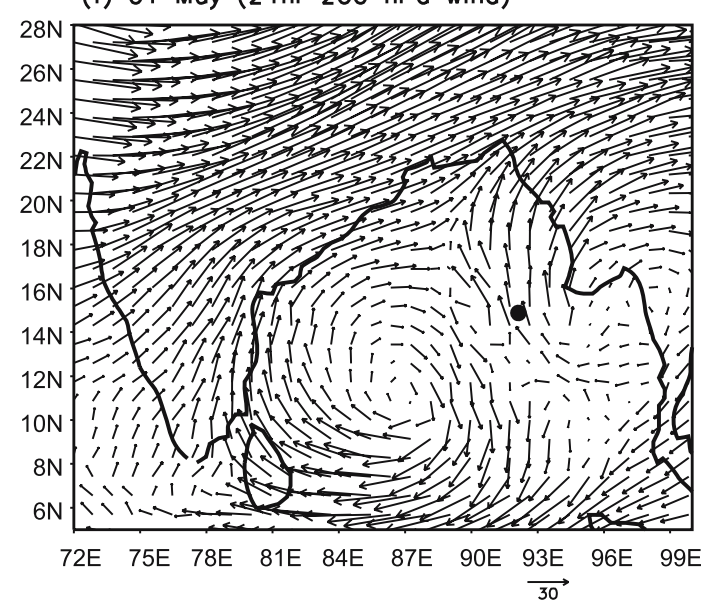

Figure 14. $200 \mathrm{hPa}$ forecast wind over Indian region from WRF (2.2) model run for the cyclone 'Nargis' from different initial date from 28 April to 1 May. (a) $48 \mathrm{~h}$ forecast wind of 28 April at 00 UTC (valid for 30 April) and the black closed circle indicates the $48 \mathrm{~h}$ forecast position of Nargis valid for 30 April. Similar descriptions for the other figures.

before the landfall). The official forecast (consensus forecast) issued by IMD at 06 UTC on 1 May $(36 \mathrm{~h}$ in advance of landfall) indicated the landfall error of $110 \mathrm{~km}$ and landfall time error of $3^{1 / 2} \mathrm{~h}$. Similarly the landfall error was $110 \mathrm{~km} 24 \mathrm{~h}$ in advance and $55 \mathrm{~km} 12 \mathrm{~h}$ in advance with landfall time error of
1-2 h. As part of the Regional Specialised Meteorological Centre (RSMC) responsibility under the World Meteorological Organisation (WMO) IMD had provided an advance information of landfall of 'Nargis' in Myanmar prior to $36 \mathrm{~h}$. The same was appreciated by the WMO. 
(a) $28 \mathrm{Apr}(72 \mathrm{hr}-48 \mathrm{hr}) \mathrm{MSLP}$

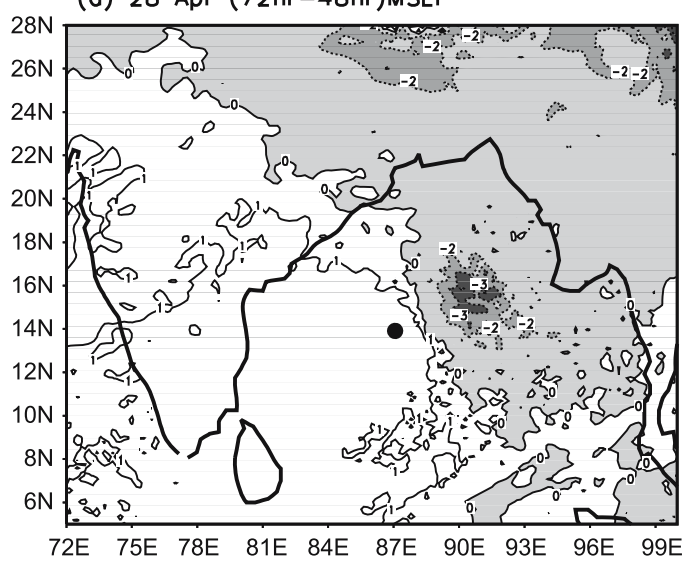

(b) $29 \mathrm{Apr}(72 \mathrm{hr}-48 \mathrm{hr}) \mathrm{MSLP}$

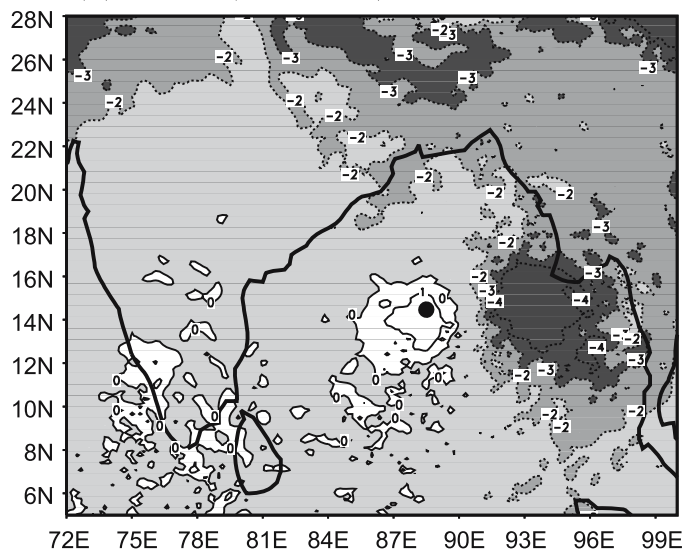

(c) $30 \mathrm{Apr}(48 \mathrm{hr}-24 \mathrm{hr}) \mathrm{MSLP}$

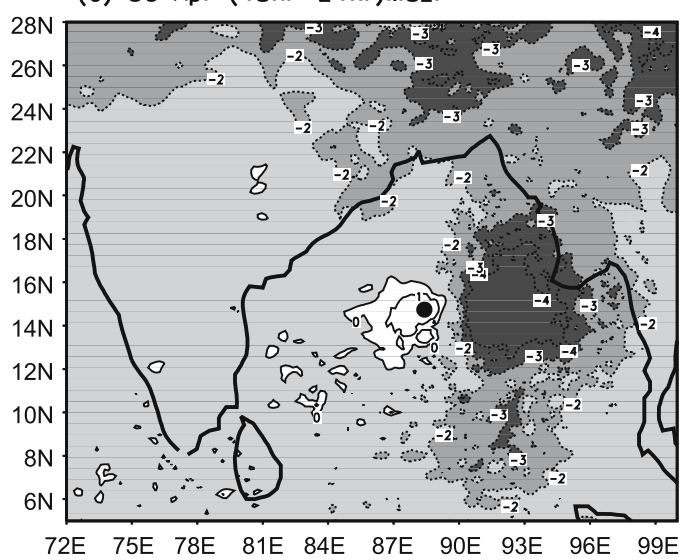

(d) $30 \mathrm{Apr}(72 \mathrm{hr}-48 \mathrm{hr}) \mathrm{MSLP}$

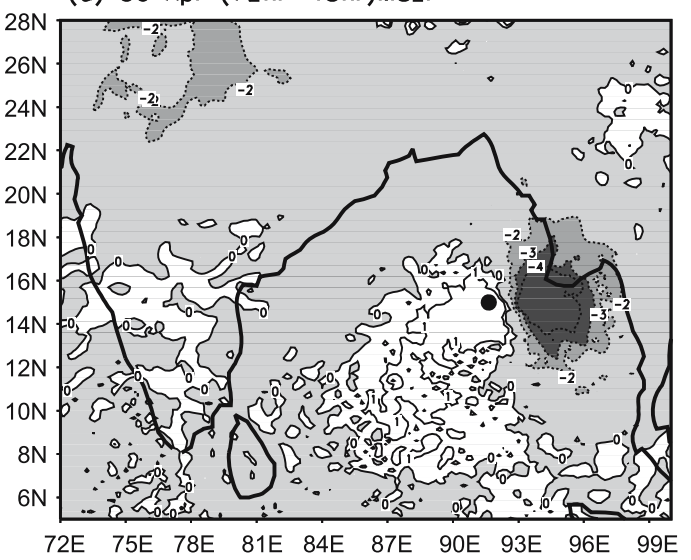

(e) 01 May $(24 \mathrm{hr}-00 \mathrm{hr})$ MSLP

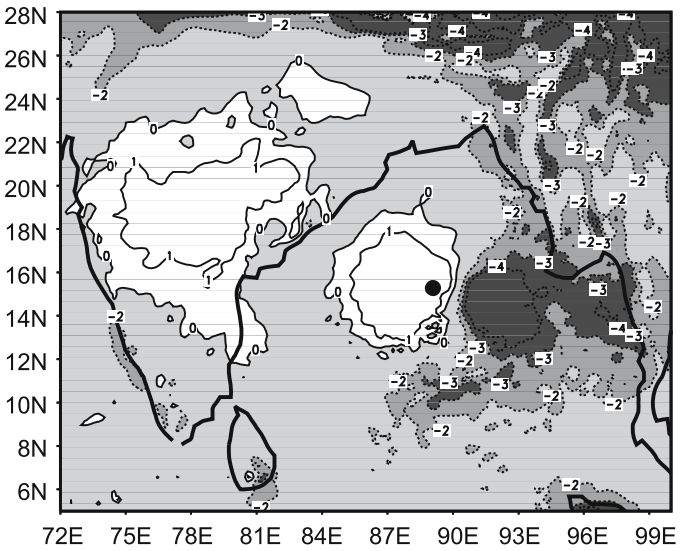

(f) 01 Moy $(48 \mathrm{hr}-24 \mathrm{hr}) \mathrm{MSLP}$

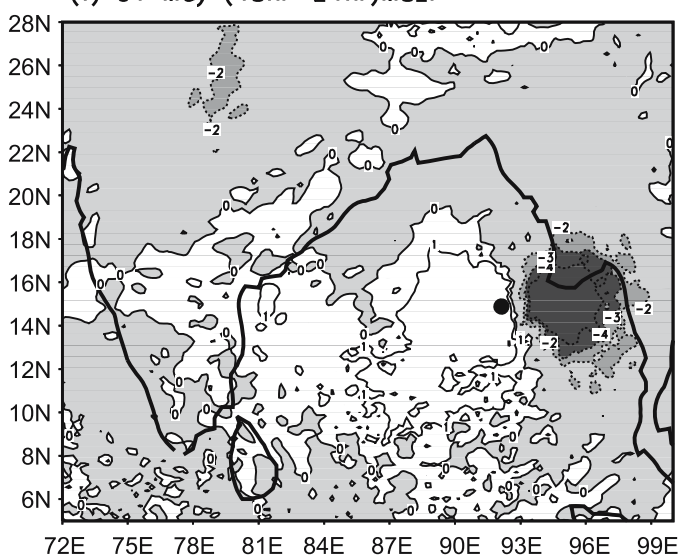

Figure 15. The $24 \mathrm{~h}$ mean sea level pressure change over Indian region from WRF model run for the cyclone of 'Nargis' from different initial date from 28 April to 01 May. (a) $72-48 \mathrm{~h}$ forecast MSLP of 28 April at 00 UTC (valid for 1 May MSLP-30 April MSLP at 00 UTC) and the black closed circle indicates the $48 \mathrm{~h}$ forecast position of 'Nargis' valid for 30 April. Similar descriptions for the other figures also.

\section{Conclusions}

The following broad conclusions are drawn from the above results and discussion.

The VSCS 'Nargis' over the east-central Bay of Bengal had a very long easterly movement for a period of about $30 \mathrm{~h}$ from $06 \mathrm{UTC}$ of 1 May till 15 UTC of 2 May before hitting the coast of Myanmar. The easterly/east-northeasterly movement of the VSCS 'Nargis' was mainly due to (i) upper level southerly/southwesterly steering wind at $200 \mathrm{hPa}$ level over the region associated with presence of an anticyclone in the southeast of the system centre; (ii) higher SST $\left(29^{\circ} \mathrm{C}\right.$ or more) over the region to the northeast of cyclone centre with positive anomalies in the east/northeast 
sector; (iii) large negative $24 \mathrm{~h}$ pressure change to the east of the storm centre; (iv) large vorticity maximum to the east of the centre of the system.

The real time track forecast using the WRF model at $27 \mathrm{~km}$ and $20 \mathrm{~km}$ resolution based on the initial conditions of 28 April (when the system was only $550 \mathrm{~km}$ away from the Indian coast) indicated that the system was not expected to cross the Indian coast. Similarly, based on 29 April initial condition the system showed east/eastnortheasterly movement towards the Myanmar coast. The east/east-northeasterly movement of the 'Nargis' was persisting in the forecast based on 30 April and 1 May initial conditions with landfall error of $85 \mathrm{~km}$ and $50 \mathrm{~km}$ in with $27 \mathrm{~km}$ resolution, which reduces to $30 \mathrm{~km}$ and $40 \mathrm{~km}$ in WRF model with $20 \mathrm{~km}$ resolution respectively with a landfall time delay of about $10 \mathrm{~h}$. Thus, it is very clear that the advanced version WRF model in the real time forecast had captured very well the movement of VSCS 'Nargis' reasonably well almost $72 \mathrm{~h}$ in advance with very less forecast error. Consistence with the diagnostic analysis the WRF model forecast also indicates southerly/southwesterly strong steering wind at $200 \mathrm{hPa}$ level and maximum pressure fall to the east of the system. Although the mean forecast errors obtained in case of the VSCS 'Nargis' are much less as compared to the mean forecast error from QLM and other global models, more number of cyclone cases have to be considered to prepare mean errors from the WRF model using different physics and dynamic options to make a proper comparison.

\section{Acknowledgements}

The authors are thankful to the Director General of Meteorology for the encouragement and for providing all facilities to carry out this study. The authors are also thankful to the reviewers for their valuable comments and suggestions, which helped a lot in improving the quality of the paper. Thanks to NCAR for making available the WRF2.2 model to carry out this study. Thanks are also due to NCEP for providing reanalyzed data and the GFS forecast fields used for the study. Thanks are also due to Dr M Mohapatra, Director, Cyclone Warning Centre, IMD for sharing the official forecast of IMD and useful discussion.

\section{References}

Chan J C L and Gray W M 1982 Tropical cyclone movement and surrounding flow relationships; Mon. Wea. Rev. 110 1354-1374.
Dudhia J 1989 Numerical study of convection observed during the winter monsoon experiment using a mesoscale two-dimensional model; J. Atmos. Sci. 46 3077-3107.

Elsberry R L, Frank W M, Holland G J, Jarrell J D and Southern R L 1987 A global view of tropical cyclones; Univ. Chicago Press, 185 pp.

Frank W M 1977 The structure and energetics of the tropical cyclone II: Dynamics and energetics; Mon. Wea. Rev. 105 $136-150$.

Gray W M 1992 Tropical cyclone formation and intensity change; In: Tropical Cyclone Disasters (eds) James Lighthill, Greg Holland, Zheng Zhemin and Keny Ommanuel, Peking University Press.

Grell G A 1993 Prognostic evaluation of assumptions used by cumulus parameterizations; Mon. Wea. Rev. 121 764-787.

Grell G A and Devenyi D 2002 A generalized approach to parameterizing convection combining ensemble and data assimilation techniques; Geophys. Res. Lett. 29 doi:10.1029/2002GL015311.

Gupta A and Bansal R K 1997 Performance of a global spectral model in predicting the track of a hurricane in the Bay of Bengal using synoptic vortex; NCMRWF, New Delhi Tech. report.

Gupta A 2006 Current status of tropical cyclone track prediction techniques and forecast errors; Mausam $\mathbf{5 7}$ 151-158.

Hong S Y, Juang H M H and Zhao Q 1998 Implementation of prognostic cloud scheme for a regional spectral model; Mon. Wea. Rev. 126 2621-2639.

Hong S Y, Dudhia J and Chen S H 2004 A revised approach to ice microphysical processes for the bulk parameterization of clouds and precipitation; Mon. Wea. Rev. 132 $103-120$.

India Meteorological Department 1996 Addendum to Storm Atlas from 1971 to 1990; India Meteorological Department.

India Meteorological Department 2003 Cyclone Manual: India Meteorological Department.

Krishna Rao A V R 1997 Tropical cyclones - synoptic methods of forecasting; Mausam 48 239-256.

Mlawer E J, Taubman S J, Brown P D, Lacono M J and Clough S A 1997 Radiative transfer for inhomogeneous atmosphere: RRTM, a validated correlated-k model for the longwave; J. Geophys. Res. 102(D14) $16,663-16,682$.

McAdie C J and Lawrence M B 2000 Improvements in tropical cyclone track forecasting in the Atlantic basin; Bull. Am. Meteor. Soc. 81 989-997.

Mohanty U C and Gupta Akhilesh 1997 Deterministic methods for prediction of tropical cyclone tracks; Mausam 48 257-272.

Prasad K and Rama Rao Y V 2003 Cyclone Track prediction by a quasi-Lagrangian model; Meteorol. Atmos. Phys. $\mathbf{8 3}$ 173-185.

Richie E A, Holland G J and Lander M 1993 Contribution of mesoscale convective systems to movement and formation of Tropical Cyclones; In: Tropical Cyclone Disaters (eds) James Lighthill, Greg Holland, Zhemin and Kerry Emanues, Peking University Press, 286-289.

Sikka D R and Suryanarayana R 1972 Forecasting the movement of tropical storms/depressions in the Indian region by computer oriented technique wing climatology and persistence; Indian J. Met. Geophys. 23 $35-40$.

Singh S S and Saha K R 1978 Numerical experiment with a primitive equation barotropic model using quasiLagrangian advection scheme to predict the movement 
of monsoon depressions and tropical cyclones; Indian J. Met. Geophys. 29 367-374.

Skamarock W C, Klemp J B, Dudhia J, Gill D O, Barker D M, Wang W and Powers J G 2005 A description of the advanced research WRF Version 2; NCAR Tech. Note, NCAR/TN-468+STR, $88 \mathrm{pp}$.

Srinivasan V and Ramamurthy K 1973 Forecasting Mannual No. IV 18.4; India Meteorological Department.

MS received 4 June 2008; revised 15 December 2008; accepted 19 December 2008 